\title{
Characterization of the Reaction Layer or Film on PNL Inert Anodes: Progress Report for April-December 1989
}

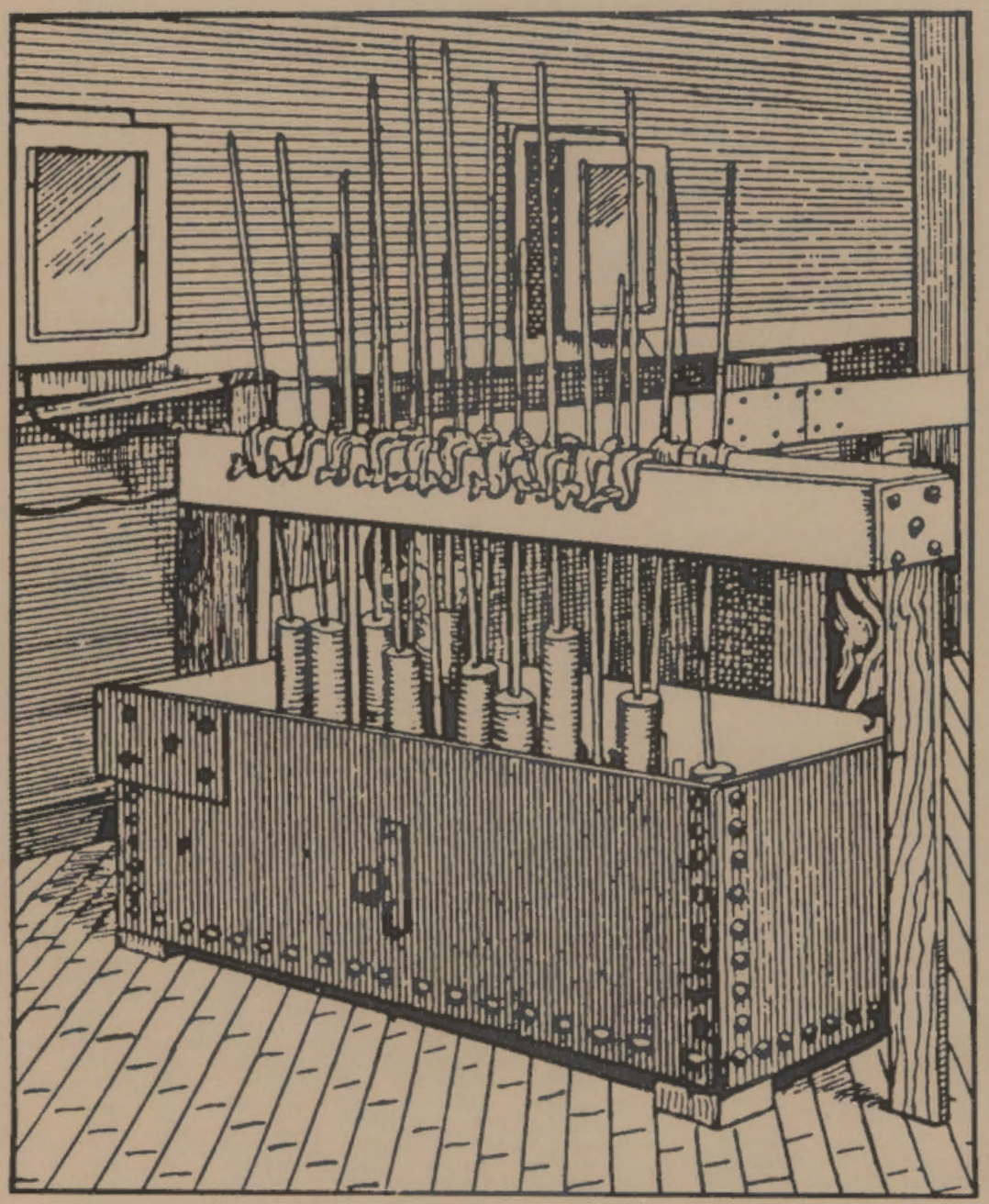

May 1990

Prepared for the U.S. Department of Energy under Contract DE-AC06-76RLO 1830

Pacific Northwest Laboratory Operated for the U.S. Department of Energy by Battelle Memorial Institute 


\title{
On the cover:
}

\section{Aluminum reduction pots at the Pittsburgh Reduction Company's (Alcoa's) plant in 1889. Adapted from a photograph, courtesy of Alcoa.}

\section{DISCLAIMER}

This report was prepared as an account of work sponsored by an agency of the United States Government. Neither the United States Government nor any agency thereof, nor Battelle Memorial Institute, nor any of their employees, makes any warranty, expressed or implied, or assumes any legal liability or responsibility for the accuracy, completeness, or usefulness of any information, apparatus, product, or process disclosed, or represents that its use would not infringe privately owned rights. Reference herein to any specific commercial product, process, or service by trade name, trademark, manufacturer, or otherwise, does not necessarily constitute or imply its endorsement, recommendation, or favoring by the United States Government of any agency thereof, or Battelle Memorial Institute. The views and opinions of authors expressed herein do not necessarily state or reflect those of the United States Government or any agency thereof.

\author{
PACIFIC NORTHWEST LABORATORY \\ operated by \\ BATTELLE MEMORIAL INSTITUTE \\ for the \\ UNITED STATES DEPARTMENT OF ENERGY \\ under Contract DE-AC06-76RLO 1830
}

\author{
Printed in the United States of America \\ Available to DOE and DOE contractors from the \\ Office of Scientific and Technical Information, P.O. Box 62, Oak Ridge, TN 37831; \\ prices available from (615) 576-8401. FTS 626-8401.
}

Available to the public from the National Technical Information Service,

U.S. Department of Commerce, 5285 Port Royal Rd., Springfield, VA 22161.

NTIS Price Codes, Microfiche A01

Printed Copy

\begin{tabular}{lrrrr}
\hline Price Code & Page Range & & Price Code & Page Range \\
\cline { 5 - 5 } A02 & $1-10$ & & A15 & $326-350$ \\
A03 & $11-50$ & A16 & $351-375$ \\
A04 & $51-75$ & A17 & $376-400$ \\
A05 & $76-100$ & A18 & $401-425$ \\
A06 & $101-125$ & A19 & $426-450$ \\
A07 & $126-150$ & A20 & $451-475$ \\
A08 & $151-175$ & A21 & $476-500$ \\
A09 & $176-200$ & A22 & $501-525$ \\
A10 & $201-225$ & A23 & $526-550$ \\
A11 & $226-250$ & A24 & $551-575$ \\
A12 & $251-275$ & A25 & $576-600$ \\
A13 & $276-300$ & A99 & $601-U p$ \\
A14 & $301-325$ & &
\end{tabular}


Inert Electrodes Program

CHARACTERIZATION OF THE REACTION

LAYER OR FILM ON PNL INERT ANODES:

PROGRESS REPORT FOR APRIL - DECEMBER 1989

C. F. Windisch, Jr.

N. D. Stice

May 1990

Prepared for

the U.S. Department of Energy

under Contract DE-ACO6-76RLO 1830

Pacific Northwest Laboratory

Richland, Washington 99352 



\section{SUMMARY}

This progress report addresses activities conducted at Pacific Northwest Laboratory (PNL) between April 1989 and December 1989 to characterize the reaction layer or film previously proposed by PNL to form on cermet anodes during the electrolytic production of aluminum in Hall-Heroult cells. Formation of this resistive film was thought to protect the cermet anode from corrosion reactions that would otherwise occur in the molten cryolite electrolyte.

The results of potential-step studies, electrochemical impedance spectroscopy, and post-mortem microscopic analys is of polarized anodes suggest that the processes of corrosion of the metallic phase of the anode and the production of oxygen gas are separable and exhibit very different kinetic behavior. The corrosion reactions occur predominantly at low anode potentials, appear to show diffusion control, and may be related to the porosity of the anode. The oxygen production reaction is the predominant reaction above $2.2 \mathrm{~V}$, exhibits activation control, occurs primarily on the surface of the anode, and is accompanied by an increase in surface roughness at higher current densities.

Evidence presented in this report indicates that the production of oxygen shuts down the corrosion reactions, possibly through a pore-blocking mechanism. In addition, roughness effects may help explain some of the impedance relationships previously observed by PNL for these anodes. Although the present results do not rule out the formation of a protective layer or film, they strongly indicate mechanisms other than the formation of a macroscopic protective film for the apparent attenuation of corrosion reactions at typical operating current densities. 
.

- .

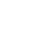

.

.

. 


\section{ACKNOWLEDGMENTS}

The authors acknowledge the assistance of the staff at Pacific Northwest Laboratory (PNL), in particular the managerial guidance provided by L. G. Morgan, the technical contributions of 0 . H. Koski and D. M. Strachan, the microscopy work done by N. T. Saenz, and the secretarial support by D. L. Schneider. We are also grateful for the programmatic assistance provided by M. J. McMonigle, Office of Industrial Programs, U.S. Department of Energy (DOE), Washington, DC, and D. R. Segna, Richland Operations Office, DOE; and the programmatic support provided by the Office of Industrial Programs, DOE. 


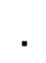

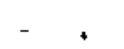




\section{CONTENTS}

SUMMARY. ........................... $i$ i

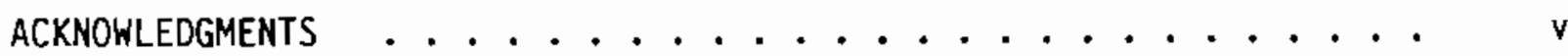

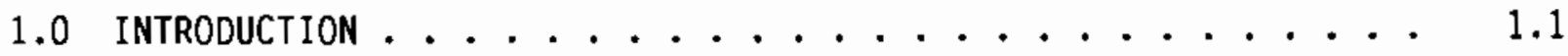

2.0 APPROACH TO FILM CHARACTERIZATION IN FY $1989 \ldots \ldots . \ldots . \ldots . . \ldots$

2.1 POTENTIAL-STEP TESTS . . . . . . . . . . . . 2.1

2.2 ELECTROCHEMICAL IMPEDANCE SPECTROSCOPY (EIS) $\ldots \ldots . . . .2$.

2.3 POST-MORTEM MICROSCOPIC EXAMINATION OF

POLARIZED ANODES ...................... 2.2

3.0 EXPERIMENTAL PROCEDURE . . . . . . . . . . . . 3.1

4.0 RESULTS AND DISCUSSION . . . . . . . . . . . . 4.1

4.1 a Mathematical MOdel . . . . . . . . . . 4.1

4.2 A PHYSICAL MODEL . . . . . . . . . . . 4.17

4.2.1 Low Current Density Behavior . . . . . . . . . 4.17

4.2.2 High Current Density Behavior ......... 4.22

4.3 A PORE-BLOCKING MECHANISM ............... 4.26

4.4 THE RELATIONSHIP BETWEEN FITTING PARAMETER B AND THE CONCENTRATION OF ALUMINA . . . . . . . . . 4.27

4.5 AN EXPLANATION FOR THE ANODE IMPEDANCE RELATIONSHIP . . . 4.31

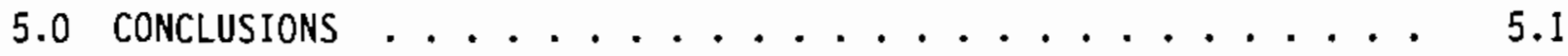

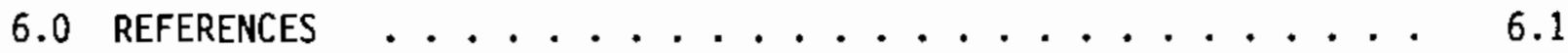




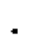

- .

.

. 


\section{FIGURES}

3.1 Apparatus for PNL Bench-Scale Laboratory Tests . . . . . . . . 3.2

4.1 Potential-Step Data for $100 \%$ Alumina and 2.0 Volts . . . . . . 4.2

4.2 Potential-Step Data for $100 \%$ Alumina and 2.0 Volts (Second Run for These Conditions) ........... 4.3

4.3 Potential-Step Data for $100 \%$ Alunina and 2.1 Volts. . . . . 4.4

4.4 Potential-Step Data for $100 \%$ Alumina and 2.3 Volts . . . . . 4.5

4.5 Potential-Step Data for $100 \%$ ATumina and 2.4 Volts . . . . . . 4.6

4.6 Potential-Step Data for $100 \%$ Alumina and 2.6 Volts . . . . . 4.7

4.7 Potential-Step Data for $75 \%$ Alumina and 2.0 Volts . . . . . 4.8

4.8 Potential-Step Data for $75 \%$ Alumina and 2.4 Volts . . . . . 4.9

4.9 Potential-Step Data for $75 \%$ Alumina and 2.5 Volts . . . . . 4.10

4.10 Potential-Step Data for 50\% Alumina and 2.0 Volts . . . . . 4.11

4.11 Potential-Step Data for 50\% Alumina and 2.4 Volts . . . . . 4.12

4.12 Plot of Fitting Parameter A Versus Fitting Parameter B for $100 \%(0), 75 \%(X)$ and $50 \%(*)$ Alumina.......... 4.15

4.13 Variation of Fitting Parameters $A$ and $B$ with Current for $100 \%(0), 75 \%(0), 75 \%(X)$ and $50 \%(*)$ Alumina ....... 4.16

4.14 Variation of Fitting Parameters $C$ and $D$ with Current for $100 \%(0), 75 \%(X)$ and $50 \%(*)$ Alumina .......... 4.18

4.15 Optical Micrographs of PNL Cermet Inert Anodes . . . . . . . . 4.20

4.16 Electrochemical Impedance Spectrum for PNL Inert Anode at 2.1 V ................ . . . . 4.21

4.17 Electrochemical Impedance Spectra for PNL Inert Anodes at Potentials above 2.1 V........................ 4.23

4.18 Porosity and Metal Phase Relationships in 0 to $50 \mu$ Surface Region of PNL Cermet Inert Anodes . . . . . . . . 
4.19 Variation of Fitting Parameter $B$ with $1 / C$ where $C$ is the Alumina Concentration in Moles $/ \mathrm{cm}^{3}$........... 4.30

4.20 Relationships of Impedance and Roughness Factors for PNL Cermet Inert Anodes...................... 433

\section{TABLES}

4.1 Fitting Parameters .................. . . . 4.13

4.2 Data For Plotting Fitting Parameter B Against Aluminum Concentration in Moles/ $\mathrm{cm}_{3}$.................... 4.31 


\subsection{INTRODUCTION}

Experimental studies conducted at Pacific Northwest Laboratory (PNL) (a) in FY 1988 and early FY 1989 indicated that the cermet inert anodes being evaluated by PNL exhibit a characteristic impedance during the electrolytic production of aluminum in bench-scale Hall-Heroult cells. This impedance was found to have the following characteristics (Strachan et al. 1988):

- It was largely resistive in nature.

- It varied as a function of current density, giving a minimum at about 0.5 $\mathrm{A} / \mathrm{cm}^{2}$.

- It appeared to depend on aTumina concentration in the electrolyte. In general, the impedance seemed to increase with increasing alumina concentration.

- It exhibited a time dependence. Different anodes gave different impedances at different times after polarization.

- At high current densities $\left(>1 \mathrm{~A} / \mathrm{cm}^{2}\right)$, discontinuous changes in the impedance occurred, causing "spikes" in the current or voltage data.

Based on these characteristics, PNL originally proposed that a resistive reaction layer or film (hereafter called "film") formed on inert anodes during electrolysis. It was argued that the formation of this film was necessary to protect the inert anode from corrosion reactions that would otherwise occur in the molten cryolite electrolyte. It was also proposed that an anode current density of $0.5 \mathrm{~A} / \mathrm{cm}^{2}$ formed a film with optimum passivating-like characteristics. At lower current densities, the $\mathrm{film}$ was proposed to be incompletely formed, resulting in corrosion of the cermet's metallic phase. At higher current densities, it was proposed that the film would become too thick and its resistance would become too high to sustain the current density. Consequently, the film would rupture, resulting in sudden and severe corrosion of the electrode's metal phase. The rupturing events in the film were indicated by sudden drops in impedance and appeared as "spikes" in the voltage data for a cell under galvanostatic (constant current) control.

(a) PNL is operated for the U.S. Department of Energy by Battelle Memorial Institute under Contract DE-AC 06-76RLO 1830. 
It was also proposed that the quality of the film depended on the alumina concentration in the electrolyte. Higher alumina concentrations seemed to favor a more resistive, presumably thicker, film. Consequently, film rupturing behavior was considered to be more likely at high alumina concentrations (close to saturation) when current densities were above 0.5 $\mathrm{A} / \mathrm{Cm}^{2}$. Problems with reproducibility of the experimental results were encountered, however, when attempts were made to relate anode impedance explicity to alumina concentration. It was then concluded that the film impedance was dynamic, changing with time and with small fluctuations in cell conditions.

Attempts to identify the composition of the film have been largely unsuccessful (Strachan et al. 1988). Post-mortem analyses of the anode surface region have shown the presence of alumina. However, it is uncertain whether the alumina was part of a film or whether it simply precipitated from the electrolyte adhering to the anode surface during cool-down.

During the latter part of FY 1989, experiments were performed to identify the composition of the film and to determine its characteristics more precisely, particularly those that have an impact on electrolysis efficiency. This progress report presents the results of these studies. 


\subsection{APPROACH TO FILM CHARACTERIZATION}

Three principal techniques were used during this report period to characterize the film on the cermet inert anodes being evaluated at PNL: potential-step tests, electrochemical impedance spectroscopy (EIS), and postmorten microscopic examination of polarized anodes.

\subsection{POTENTIAL-STEP TESTS}

Studying the time-dependent response of the anode to a change in cell conditions was selected since the properties of the film were proposed to be dynamic (changing with time). The approach taken in these tests was to monitor the response of current with respect to time after a sudden, controlled step in anode potential. By comparing the observed current response to that expected for different types of rate control (e.g. diffusion or charge-transfer), it was hoped that some of the mechanistic details of the reactions at the anode surface could be determined.

This report covers potential-step tests on PNL inert anodes in molten cryolite. Anode potentials range from below the decomposition potential for

alumina to potentials giving current densities of about $1 \mathrm{~A} / \mathrm{cm}^{2}$. Molten cryolite baths containing alumina at $100 \%, 75 \%$, and $50 \%$ of saturation at $983^{\circ} \mathrm{C}$ were studied.

\subsection{ELECTROCHEMICAL IMPEDANCE SPECTROSCOPY (EIS)}

In these experiments, a small ac voltage signal of varying frequency was added to the controlling voltage of a cell operating potentiostatically. The resultant ac current response was measured for each frequency and used to calculate the complex impedance of the anode, also as a function of frequency. Experiments were performed for cells at various controlling anode voltages. Plots of the real versus the imaginary portions of the complex impedance over the entire frequency spectrum contain signatures that may provide mechanistic information regarding the reactions occurring at the various potentials at the anode surface. Such plots are also called Nyquist plots. 
This report discusses the results of PNL's EIS studies on cermet inert anodes in alumina-saturated molten cryolite at $983^{\circ} \mathrm{C}$ over a range of anode potentials.

\subsection{POST-MORTEM MICROSCOPIC EXAMINATION OF POLARIZED ANODES}

Optical microscopy, scanning electron microscopy (SEM), transmission electron microscopy (TEM), x-ray diffraction, and electron diffraction analys is were to be performed as needed on cermet inert anodes that had been polarized to specific potentials and current densities in molten cryolite baths of precise composition for a set period of time. It was hoped that a combination of the analytical techniques would succeed in identifying the composition of the film and determining how it depended on cell conditions, especially anode potential and alumina concentration.

Results of these studies are not yet complete. This progress report covers the results of optical microscopy on the cermet inert anodes polarized at various potentials and alumina concentrations studied by PNL. 


\subsection{EXPERIMENTAL PROCEDURE}

Experiments were performed using the bench-scale experimental setup shown in Figure 3.1. The electrochemical cell used a three electrode arrangement. The cermet inert anode was fabricated at PNL (from $\mathrm{NiO} / \mathrm{NiFe}_{2} \mathrm{O}_{4}$ oxide powder and copper metal powder to contain $17 \%$ copper by weight) according to procedures discussed in previous reports (Strachan et al. 1988). The anode was formed into the shape of a small cylinder with a cross-section of about 1 $\mathrm{cm}^{2}$. A boron nitride (BN) sheath was used to protect the walls of the anode, allowing only one of its circular faces to be exposed to the electrolyte. This face was sanded to ensure that the anode surface in contact with the electrolyte had a similar morphology for all of the anodes used in these studies. The connector bar was a nickel rod that had been brazed to the anode during the fabrication procedure as discussed in previous reports (Strachan et al. 1988). The cathode, or counter electrode, was a graphite crucible that also served as the cell container. The crucible was large enough to hold about $1 \mathrm{~kg}$ of electrolyte. No aluminum metal seed was used in these tests. The reference electrode was the $\mathrm{Al}_{1} / \mathrm{Al}_{2} \mathrm{O}_{3}$ type, fabricated according to a recently published design (Burgman, Leistra, and Sides 1986).

The electrolyte was prepared by mixing appropriate amounts of reagent grade materials to give a bath ratio equal to $1.15,5.5 \%$ (by weight) $\mathrm{CaF}_{2}$, $1.0 \% \mathrm{MgF}_{2}$, and alumina at the desired concentration. Studies were performed with alumina concentrations of $50 \%, 75 \%$, and $100 \%$ of saturation. (Alumina concentrations in this report are given as a percent of saturation, which for these test conditions is approximately $8.0 \%$ by weight.) A temperature controller/furnace/ thermocouple arrangement was used to melt the raw materials to form a "bath" and control its temperature at $983^{\circ} \mathrm{C}$. Bath ratio and temperature were effectively constant throughout these short-term tests.

The anode potential was measured and controlled using a Solartron(a) 1286 Electrochemical Interface. Voltage and current outputs were monitored in the potential-step tests using a strip chart recorder. For the EIS studies, a

(a) Solarton is a tradename of Solarton Instruments, Farmborough, Hampshire, England. 


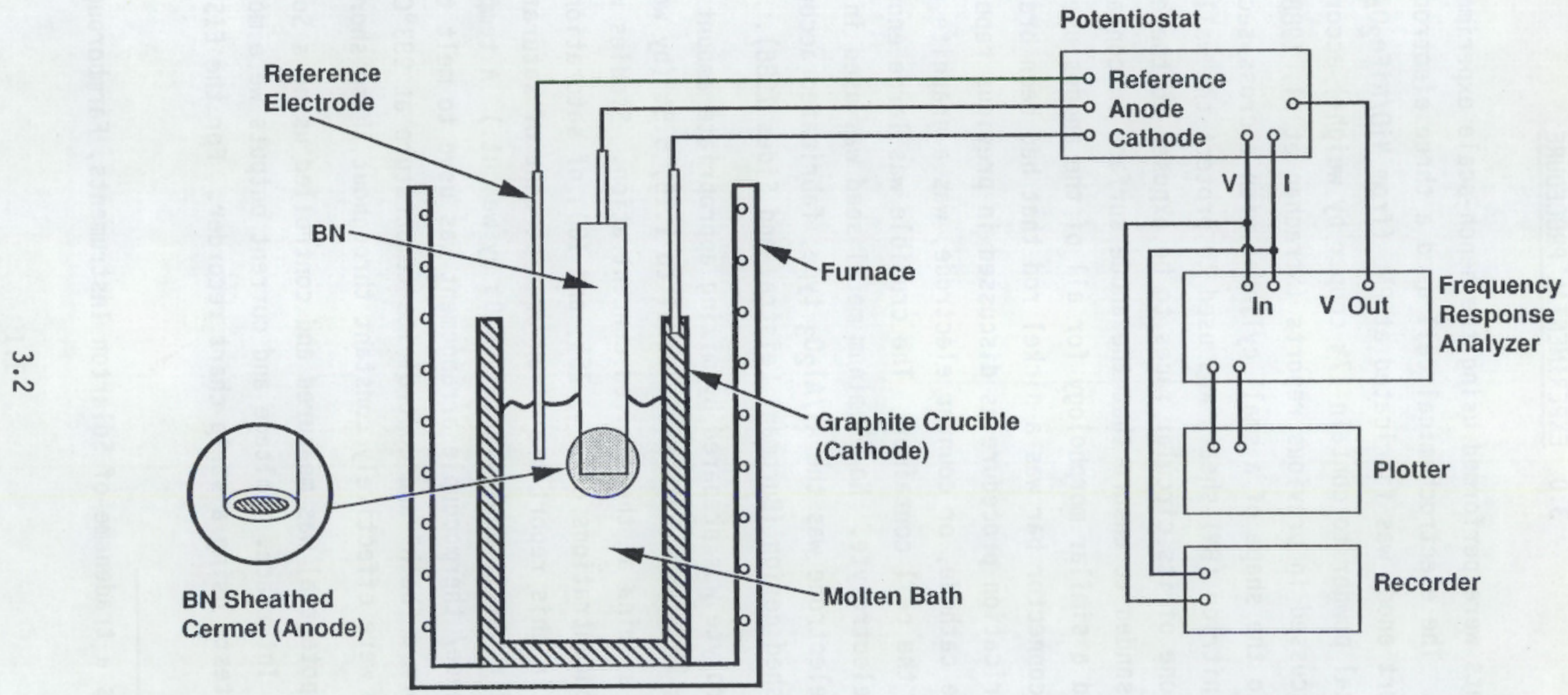

39001061.1

FIGURE 3.1. Apparatus for PNL Bench-Scale Laboratory Tests. 
Solartron 1250 Frequency Response Analyzer was used to apply a +/- $10 \mathrm{mV}$ potential to the controlling voltage, measure the current, and calculate the complex impedance. The frequency range of the excitation voltage was $0.1 \mathrm{~Hz}$ to $10 \mathrm{kHz}$ using 20 steps per decade. Nyquist plots were obtained directly on a $X Y$ plotter.

A fresh anode was used in each study performed at a given potential and bath composition. Thus, the results of each test were not subject to variations resulting from previous polarization conditions. Consequently, in a given test, the results could be considered characteristic of only one anode potential and one bath composition.

In a typical test, the bath was first made uniformly molten at $983^{\circ} \mathrm{C}$. To remove oxidizable bath impurities, a "preliminary inert anode" was then inserted and polarized to give a current of about $0.5 \mathrm{~A}$ for about $1 \mathrm{~h}$. This electrode was then removed and the test anode was inserted. The bath temperature was allowed to reequilibrate, then the potential-step test was performed. A voltage step was applied using the potentiostat while the anodeto-reference electrode potential and anode current density were monitored using the strip chart recorder. The anode was subsequently maintained at this potential for about $1 \mathrm{~h}$. Ouring this time, EIS data were collected on the anode. After the $1 \mathrm{~h}$ period, the anode was removed from the bath while still under polarization conditions; the voltage was then turned off. The anode was allowed to cool in air and then submitted for analysis. The entire procedure was then repeated with a new anode at another potential. Bath compositions were changed by starting the test over and using a different compositional mix of raw materials.

For tests with alumina concentrations less than saturation, the reference electrode suffered some deterioration because its alumina outer sheath dissolved. As a result, the reference electrode had to be replaced periodically during these studies. Based on approximate weight loss measurements, it was estimated that a maximum end-of-test error of about $10 \%$ of saturation was introduced when the alumina was initially at $50 \%$ of saturation (and the dissolution rate of the reference electrode's alumina sheath was a maximum). 


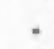

-

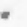




\subsection{RESULTS AND DISCUSSION}

The following is a discussion of the potential-step, EIS, and microscopy data obtained during this report period and the conclusions drawn from these data. The potential step results seem to follow a simple mathematical model. The mathematical model suggests a physical model that also appears to be consistent with the EIS and microscopy results. Although the details of this physical model are not fully resolved at this time, one possible mechanism is presented. The section concludes with discussions of data on alumina concentration dependency and surface roughness effects that support the proposed mechanism.

\subsection{A MATHEMATICAL MOOEL}

As shown in Figures 4.1 through 4.11 , the response of current to a potential-step was a sudden rise followed by a slower decay to a steady-state value. For most conditions, the majority of the current decay occurred during the first $10 \mathrm{~s}$ after the potential step was applied. This type of response occurs for many electrochemical systems but usually over a much shorter time interval. For example, the cottrell equation, which accurately models the current-time relationship for many processes under mass transfer control, is usually appropriate in the millisecond regime (Macdonald 1977). The longer response time in this work suggests that actual changes in the structure and composition of the anode's surface layers may be occurring. Structural and chemical changes can be relatively slow, as in the case of the passivation of iron (Sato and Cohen 1964).

The points plotted in Figures 4.1 through 4.11 were taken from strip chart recordings of cell current. Since the exposed surface area was $1 \mathrm{~cm}^{2}$, the ordinate values also correspond to anode current density. 


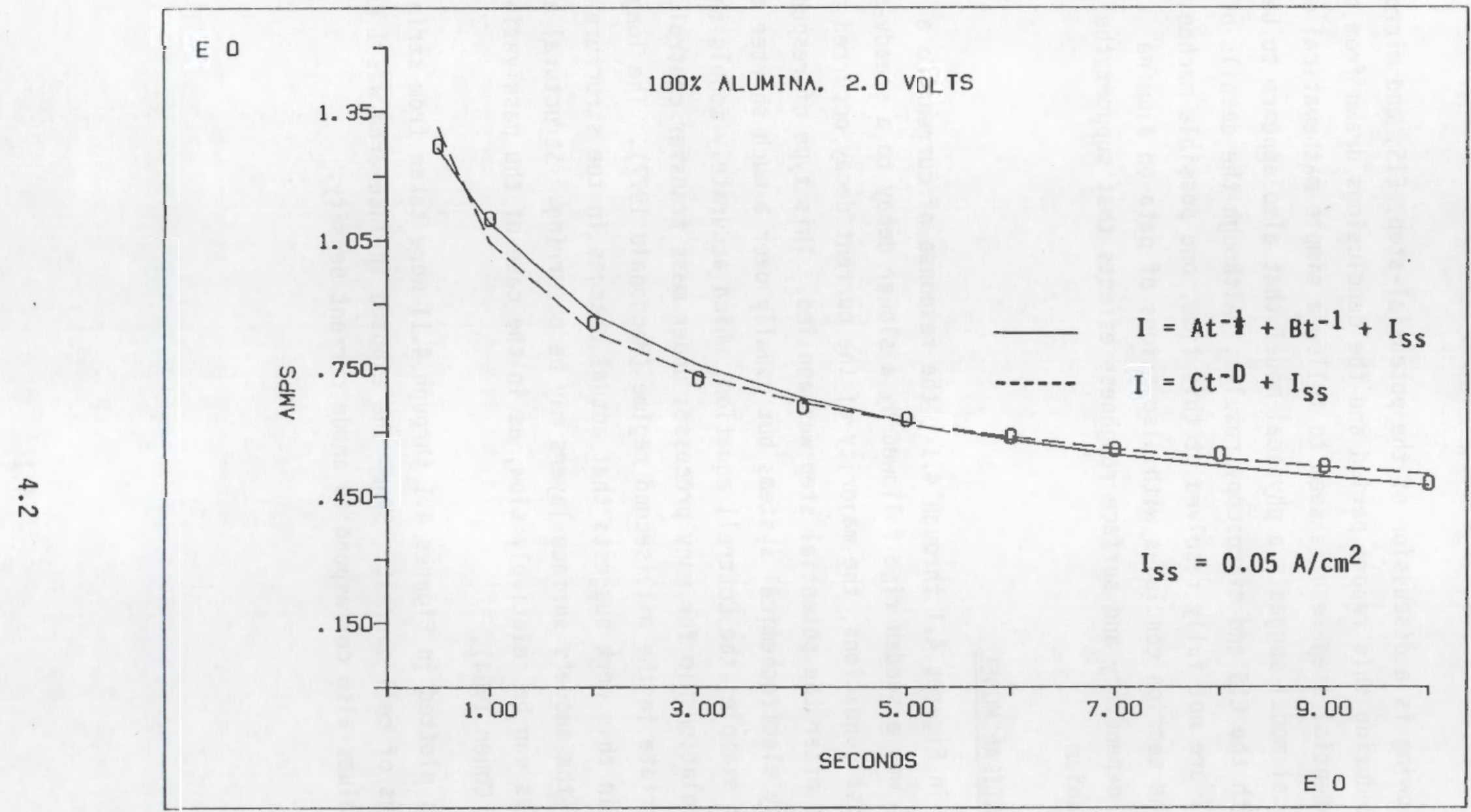

FIGURE 4.1. Potential-Step Data for $100 \%$ Alumina and 2.0 Volts. 


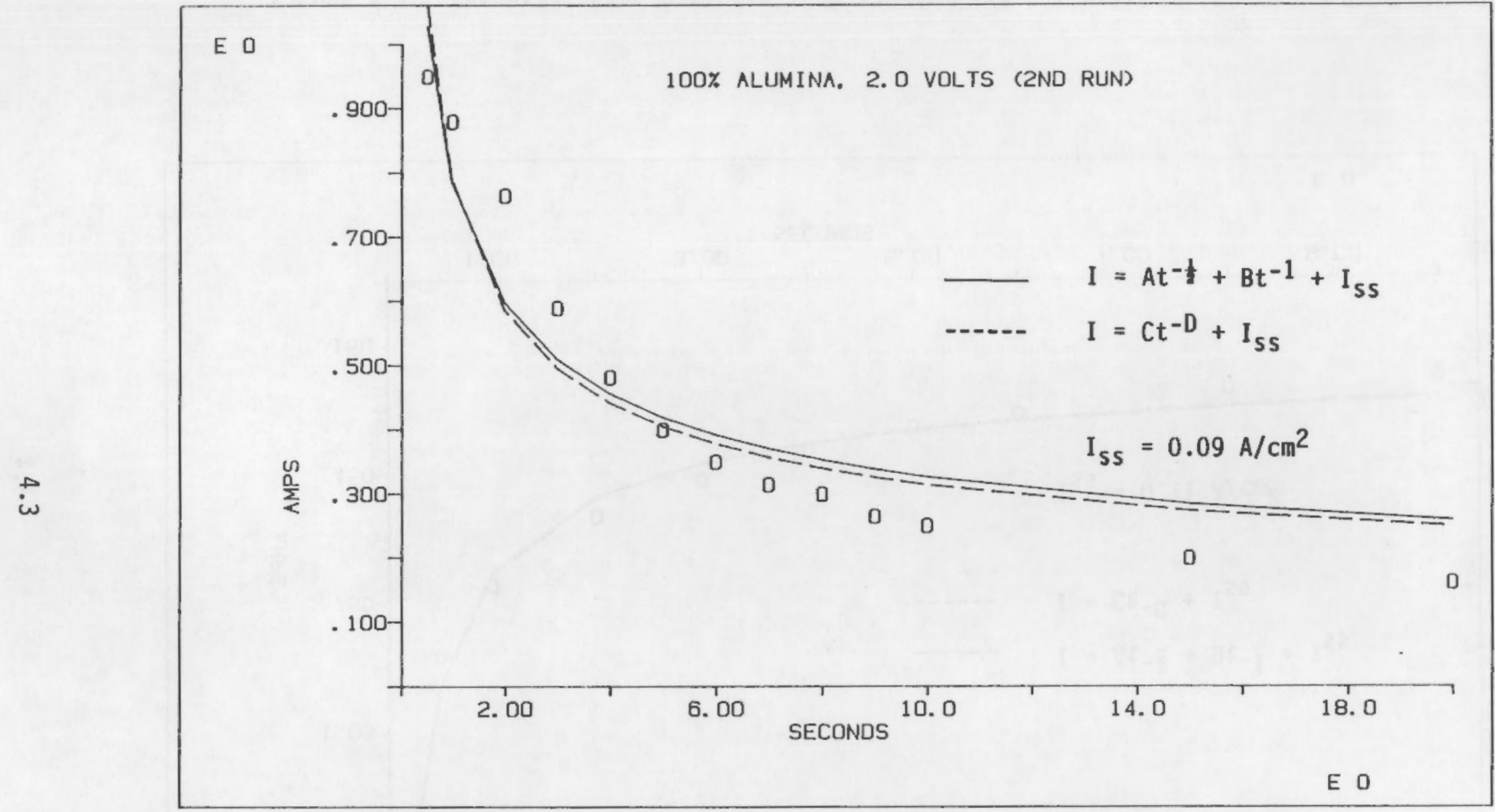

FIGURE 4.2. Potential-Step Data for 100\% Alumina and 2.0 Volts. (Second Run for These Conditions.) 


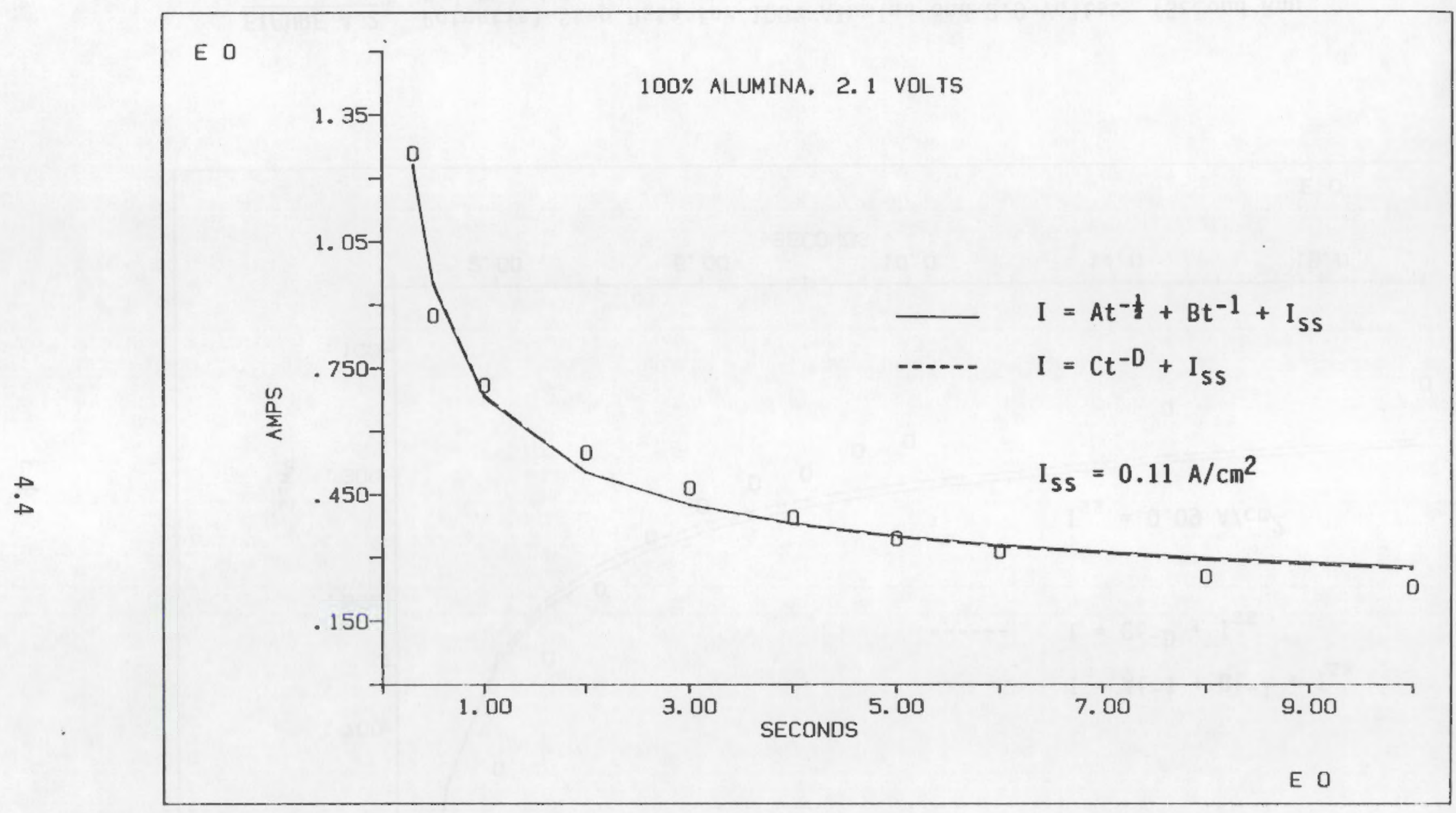

FIGURE 4.3. Potential-Step Data for $100 \%$ Alumina and 2.1 Volts. 


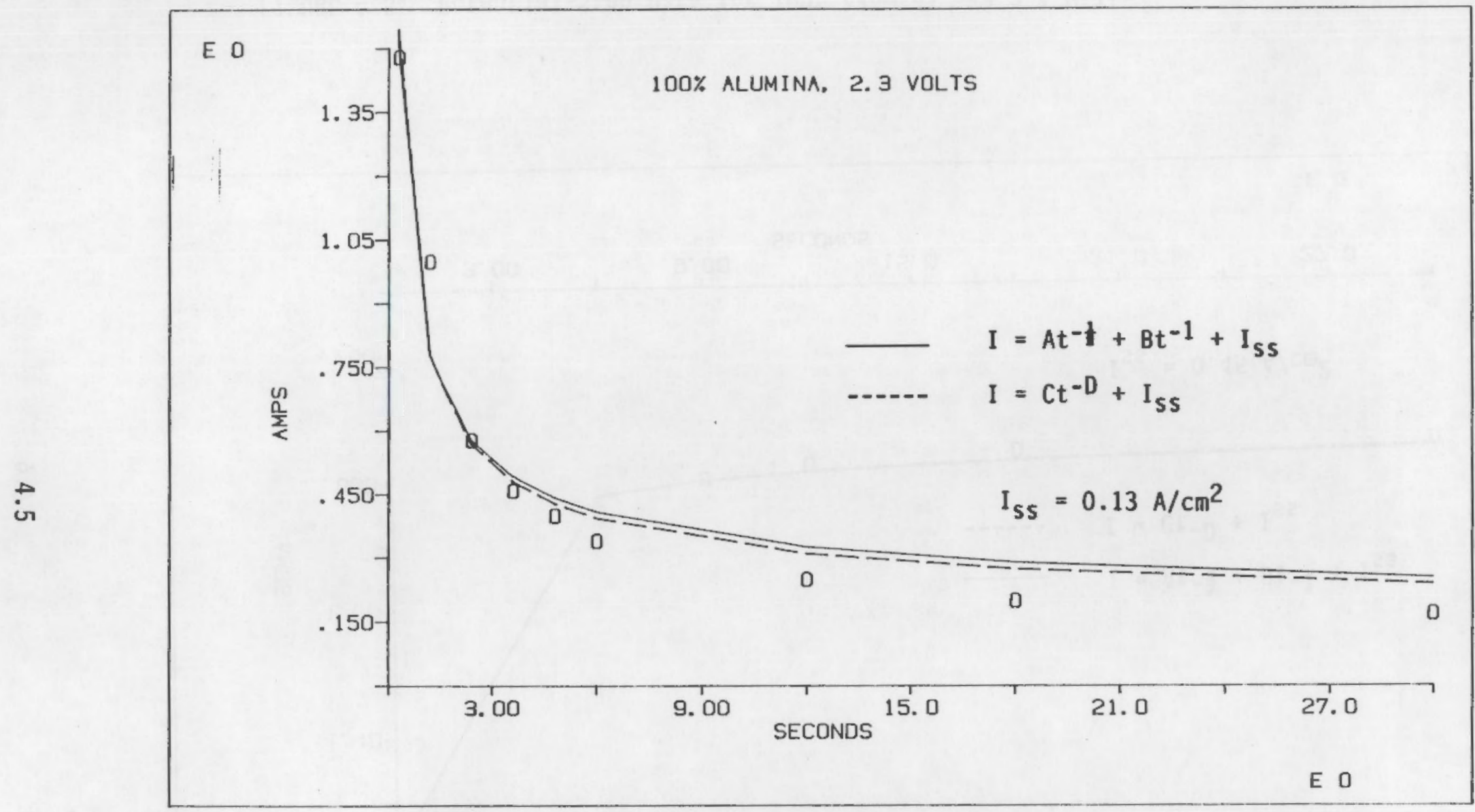

FIGURE 4.4. Potential-Step Data for $100 \%$ Alumina and 2.3 Volts. 


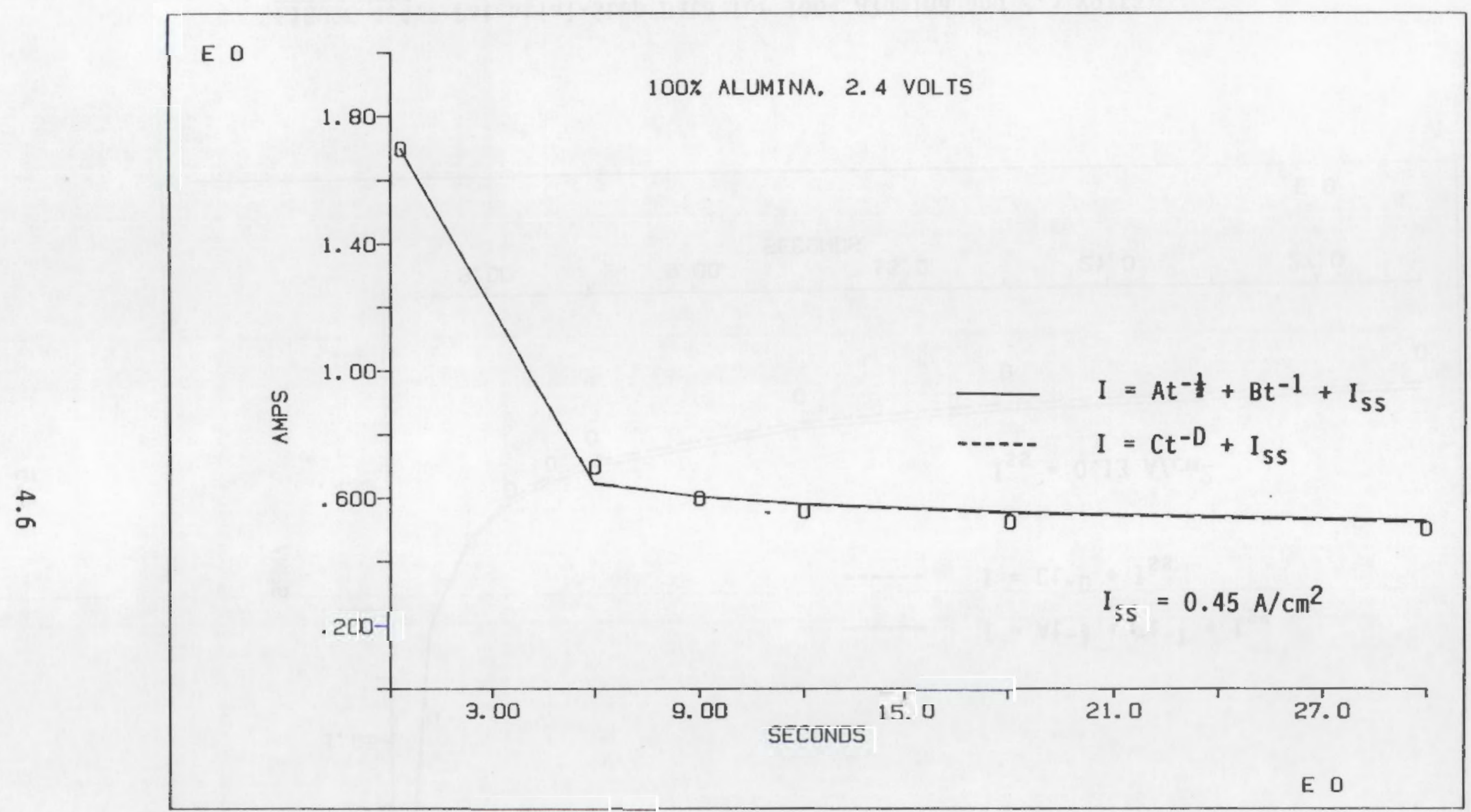

FIGURE 4.5. Potential-Step Data for $100 \%$ Alumina and 2.4 Volts. 


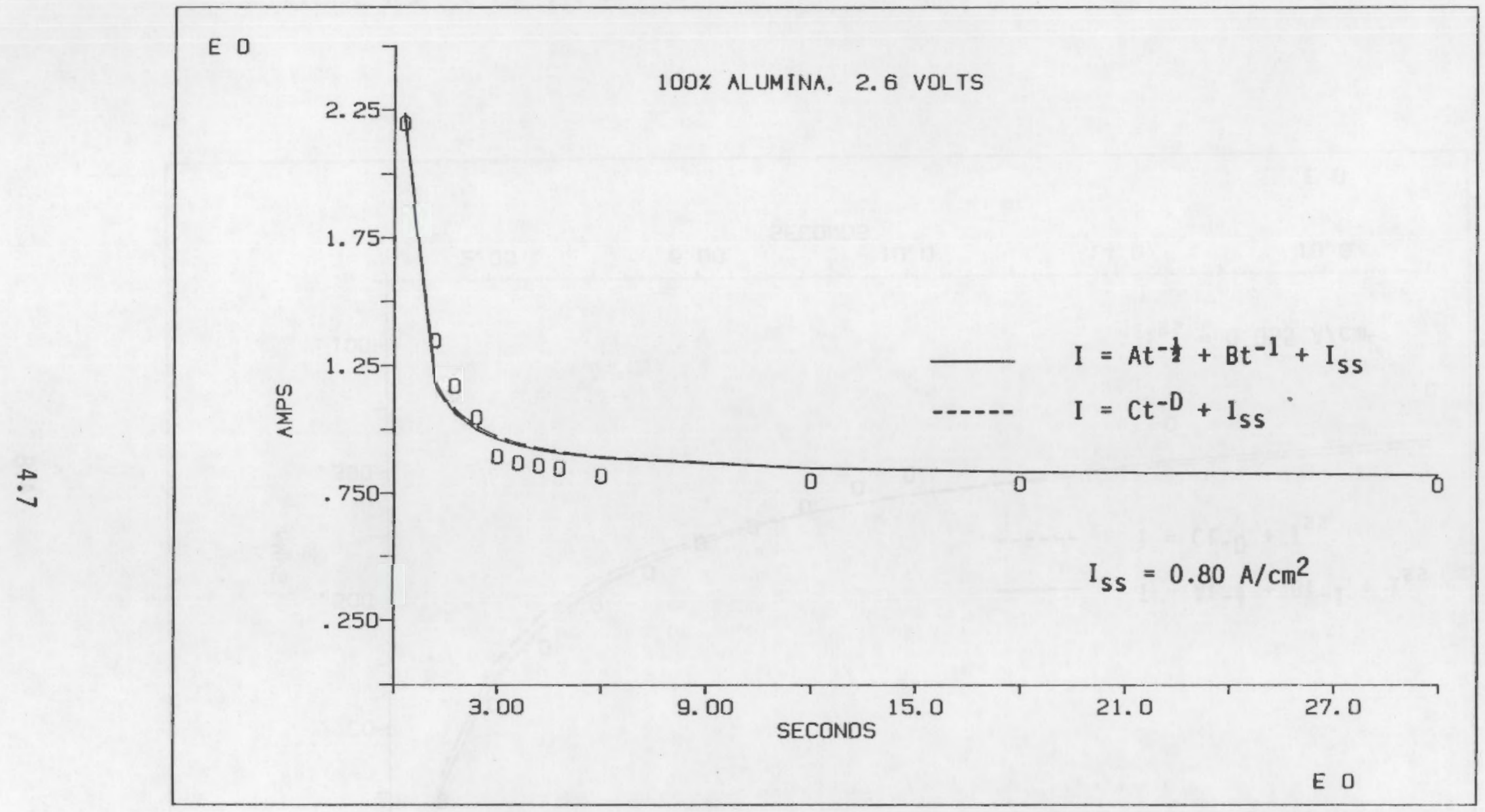

FIGURE 4.6. Potential-Step Data for $100 \%$ Alumina and 2.6 Volts. 


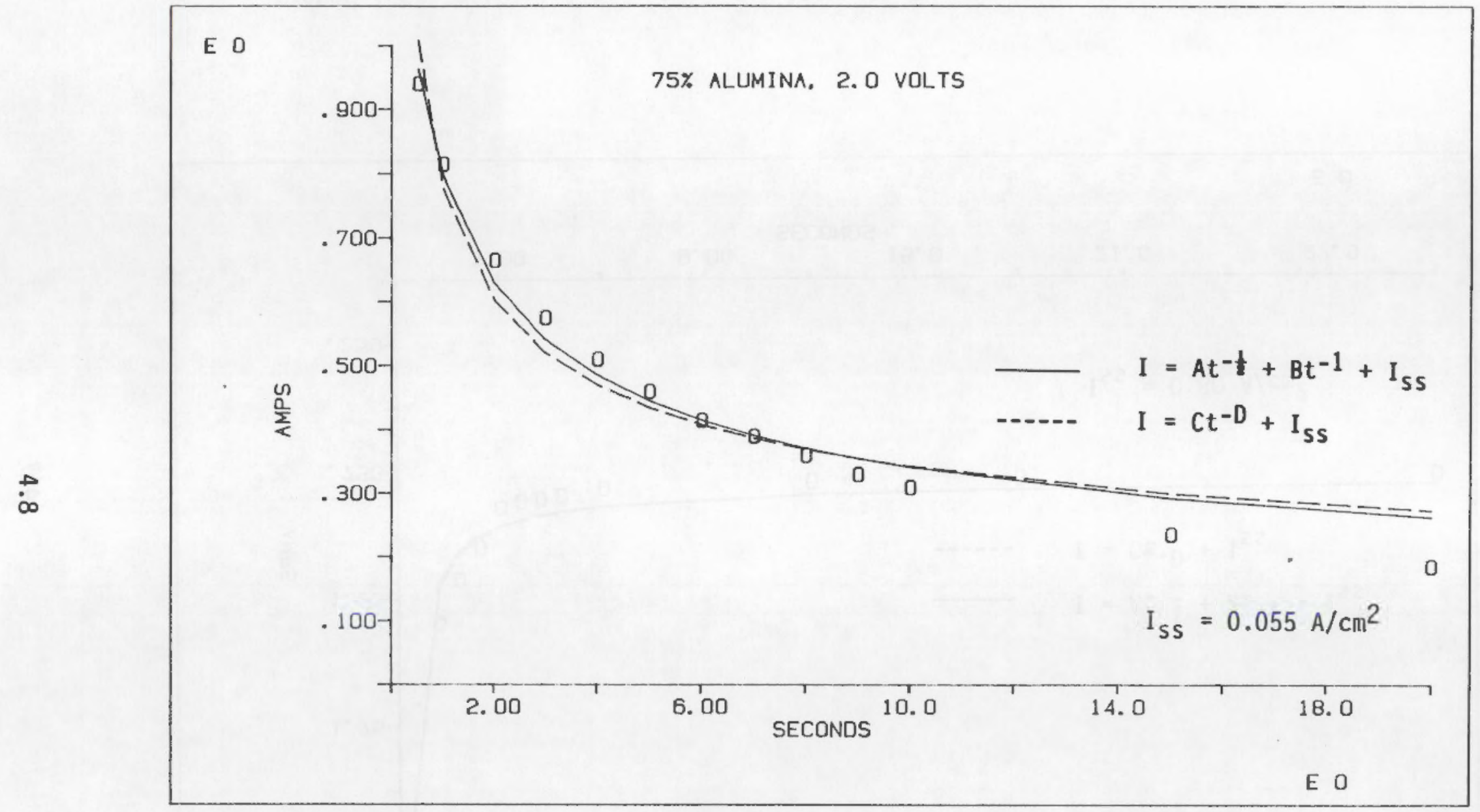

FIGURE 4.7. Potential-Step Data for $75 \%$ Alumina and 2.0 Volts. 


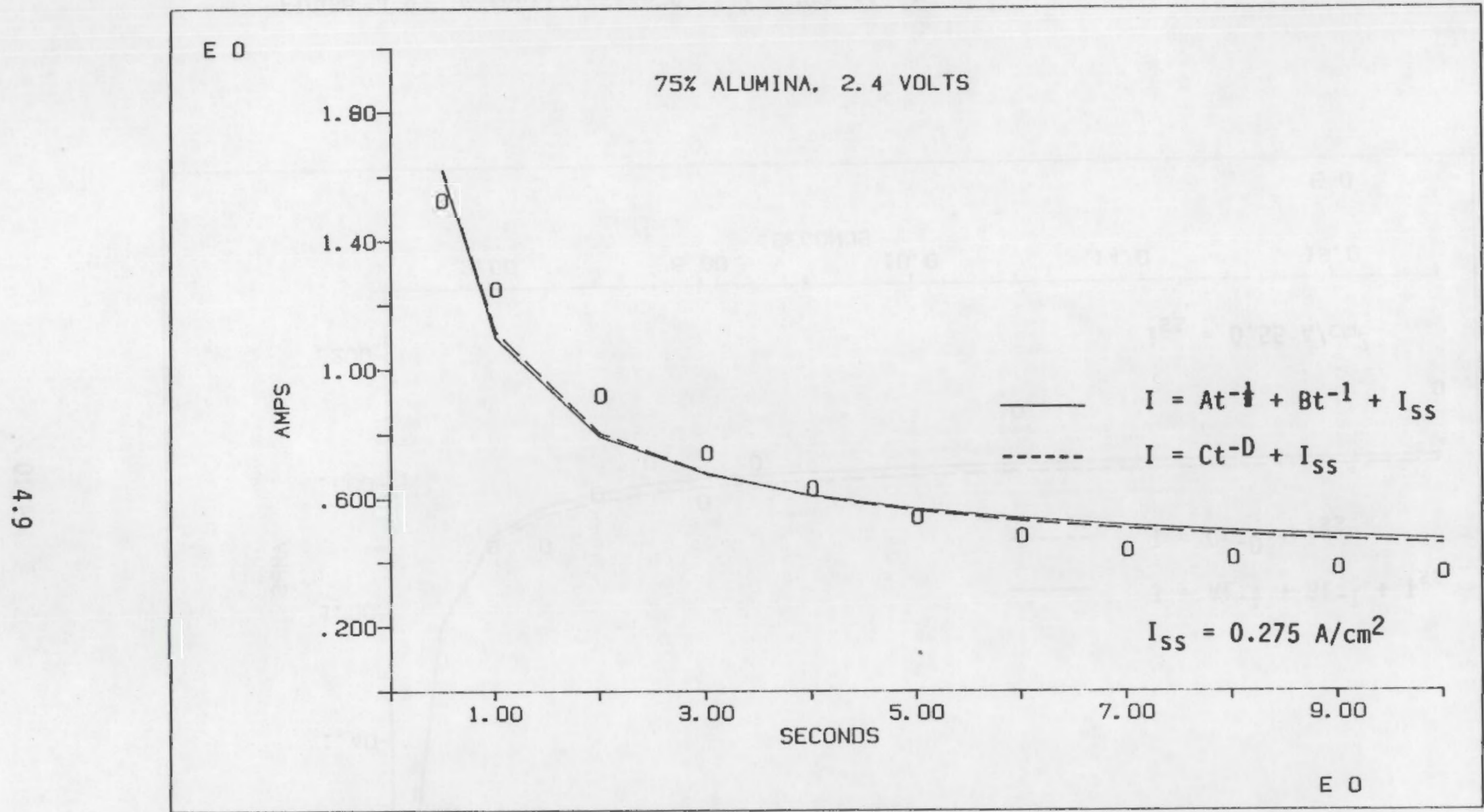

FIGURE 4.8. Potential-Step Data for $75 \%$ Alumina and 2.4 Volts. 


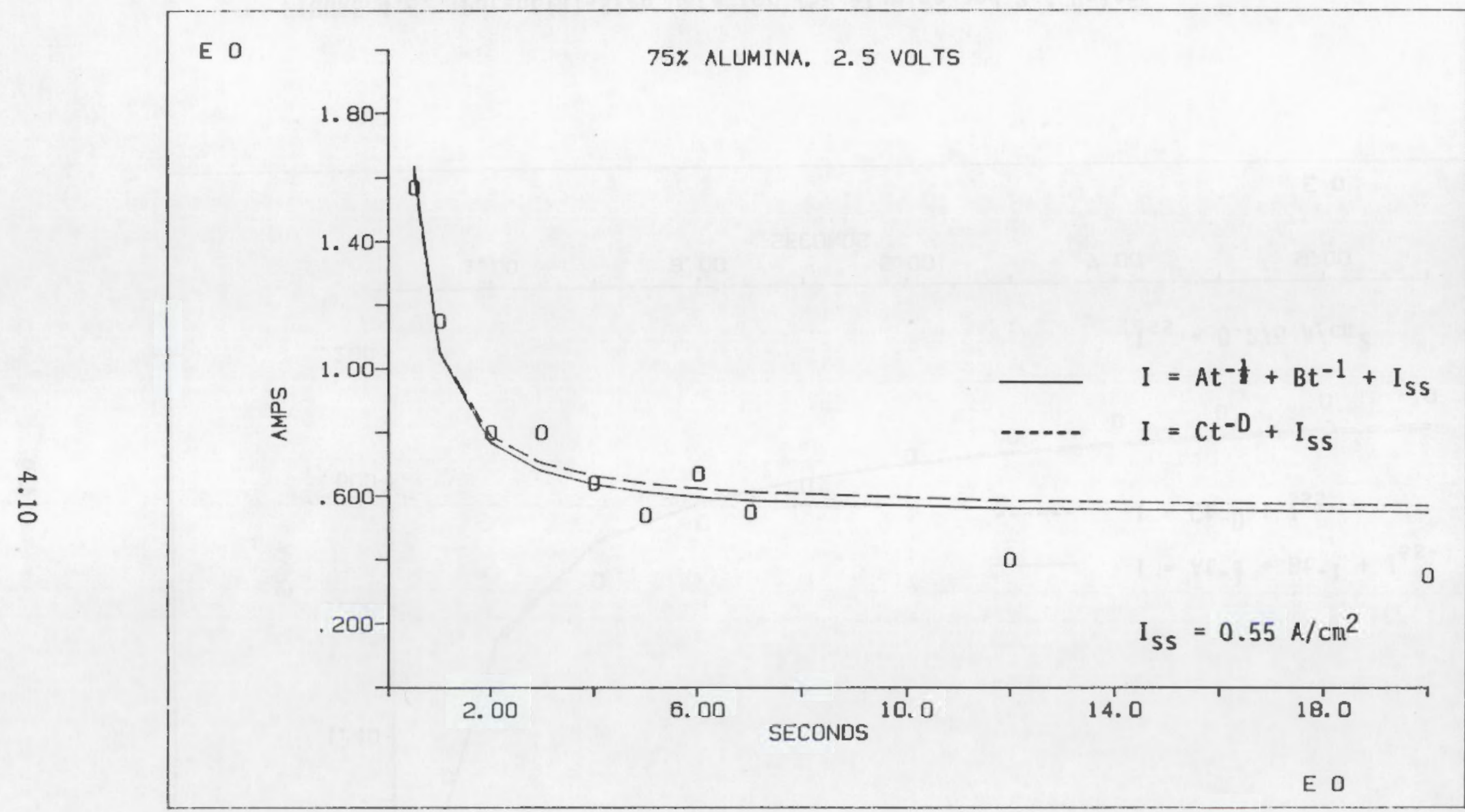

FIGURE 4.9. Potential-Step Data for $75 \%$ Alumina and 2.5 Volts. 


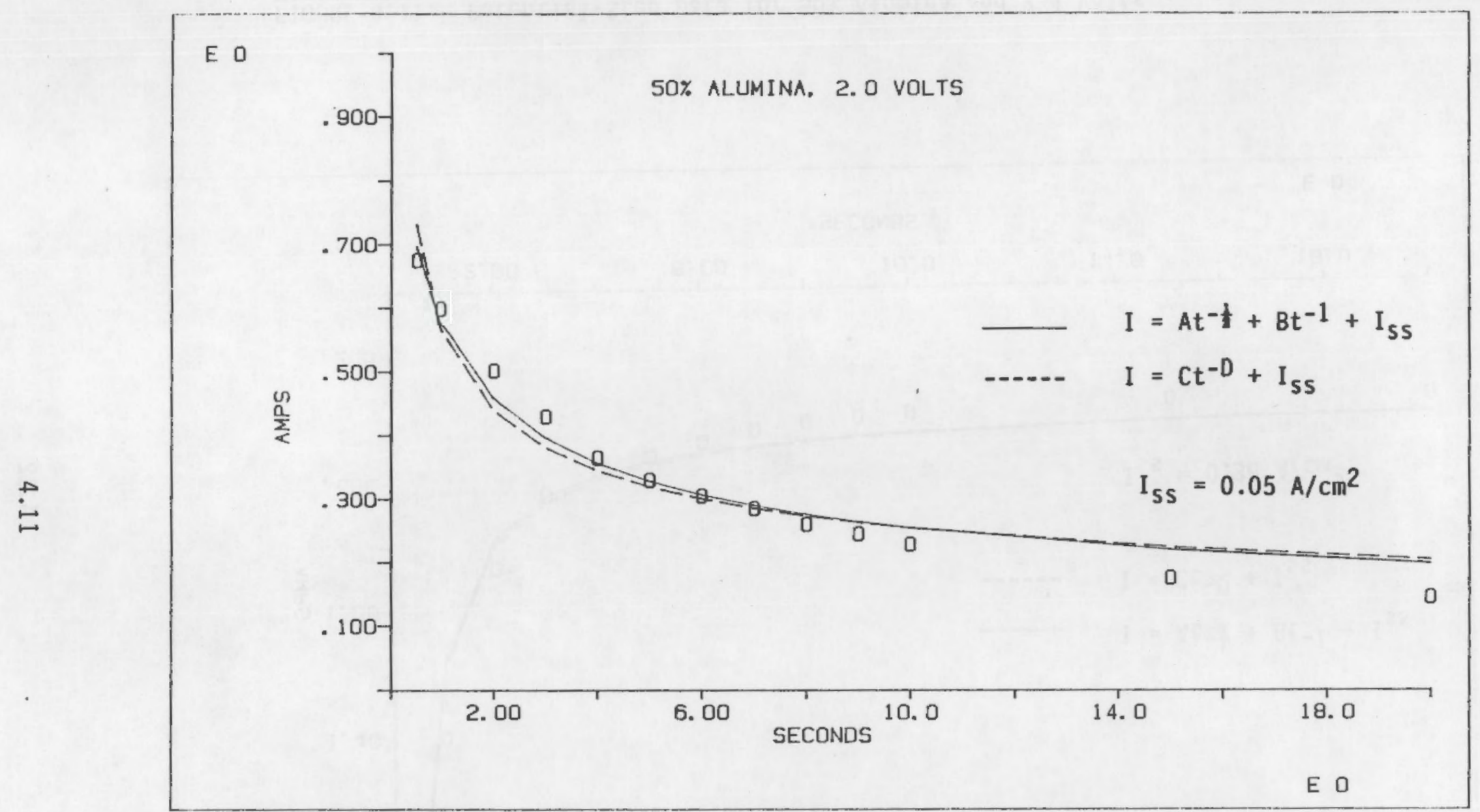

FIGURE 4.10. Potential-Step Data for 50\% Alumina and 2.0 Volts. 


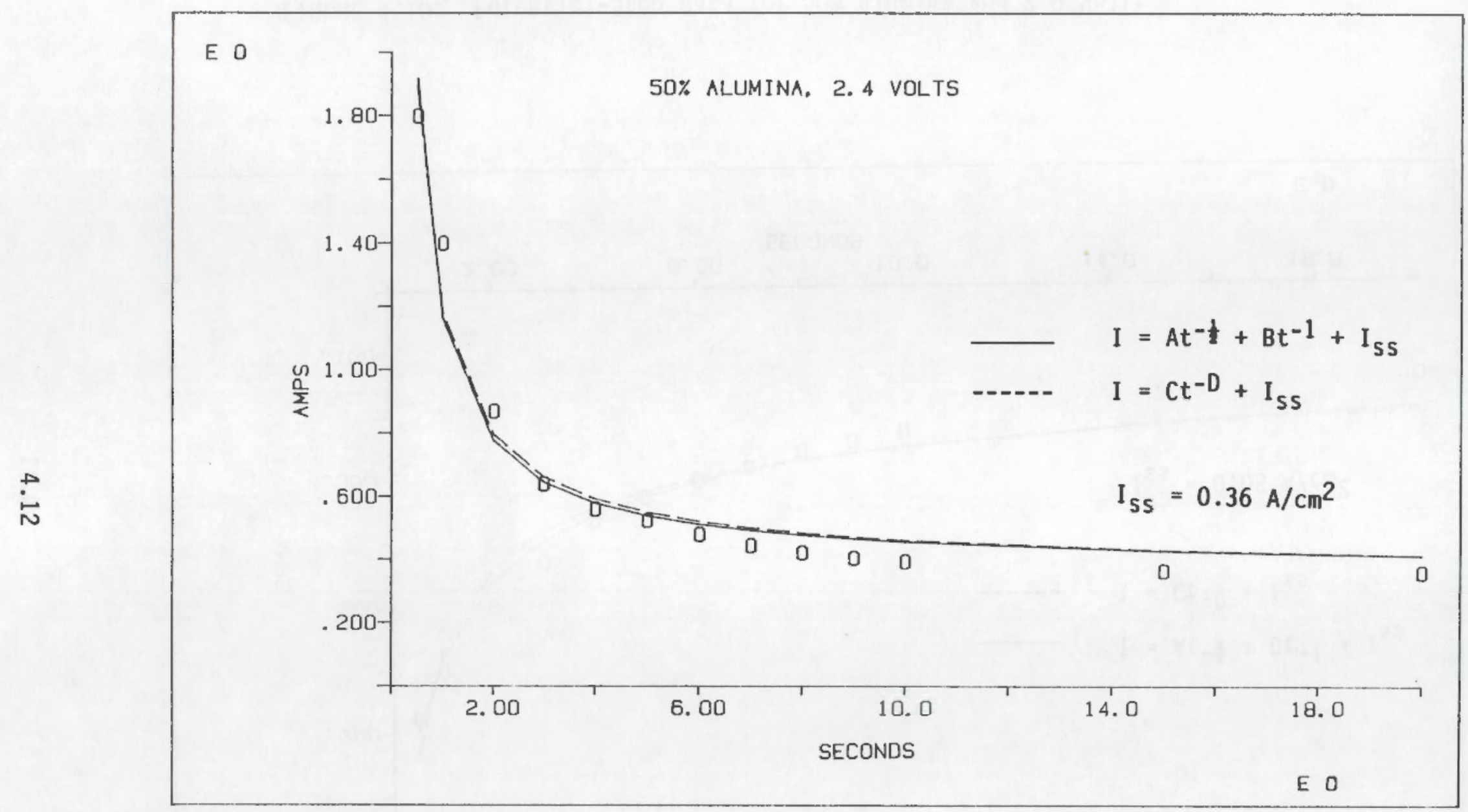

FIGURE 4.11. Potential-Step Data for $50 \%$ Alumina and 2.4 Volts. 
Various mathematical models were compared with the experimental data. To limit the number of viable solutions, no more than two fitting parameters were used in any case. Two functions that gave reasonable comparison with the experimental data were the following:

$$
\begin{aligned}
& I=A t^{-\frac{1}{2}}+B t^{-1}+I_{S S} \\
& I=C t^{-D}+I_{S S}
\end{aligned}
$$

where $I$ is the current density, $t$ is the time from when the potential step was applied, and $I_{S S}$ is the current density at steady-state $A, B, C$, and D fitting parameters. A list of the fitting parameters for the various experimental conditions tested is given in Table 4.1. The fitted curves are shown with the experimental data in Figures 4.1 through 4.11 .

\section{TABLE 4.1. Fitting Parameters}

Voltage \&

Current

Density,

$\underline{V / A} / \mathrm{cm}^{2}$

$\because \mathrm{Al}_{2} \underline{0}_{3}$

$2.0 / 0.05$

100

1.48

$\underline{B} \quad \underline{C}$

$\underline{D}$

$\underline{R}^{2}(4.1)$

(a) $\underline{R}^{2} \underline{(4.2)}^{(a)}$

$2.0 / 0.09$

100

0.77

$-0.44$

1.00

0.34

0.999

0.999

2.1/0.11

100

0.52

$-0.08$

0.70

0.50

0.976

0.974

2.3/0.13

100

0.66

0.06

0.58

0.55

0.996

0.996

$2.4 / 0.45$

100

0.42

0.05

0.72

0.56

0.981

0.983

$2.6 / 0.80$

$$
100
$$

0.05

0.15

0.60

0.61

0.999

0.999

$2.0 / 0.055$

75

0.98

0.40

0.48

0.91

0.995

0.996

$2.4 / 0.275$

75

0.51

$-0.24$

0.72

0.40

0.996

0.992

$2.5 / 0.55$

75

$-0.15$

0.31

0.84

0.67

0.987

0.990

$2.0 / 0.05$

50

0.70

$\begin{array}{ll}0.651 & 0.50\end{array}$

1.08

0.984

0.982

$2.4 / 0.36$

50

0.08

$\begin{array}{ll}-0.17 & 0.99\end{array}$

0.40

0.995

0.990

$\begin{array}{ll}0.73 & 0.82\end{array}$

0.91

0.988

0.989

(a) $R^{2}(1)$ and $R^{2}(2)$ are measures of the "goodness of fit" given by the square of the multiple correlation coefficient for the least squares fit using Equations (4.1) and (4.2), respectively. 
Equation (4.1) may be interpreted as the sum of three independent contributions to current density. The steady-state current, Iss, is constant and arises from the oxygen production reaction at the electrode surface(a)

$$
0^{2-} \longrightarrow 1 / 2 \mathrm{O}_{2}+2 \mathrm{e}^{-}
$$

and/or the steady-state rates of any corrosion processes involving the metallic phase of the cermet anode such as

$$
\begin{aligned}
& \mathrm{Ni} \longrightarrow \mathrm{Ni}^{2+}+2 \mathrm{e}^{-} \\
& \mathrm{Cu} \longrightarrow \mathrm{Cu}^{\mathrm{n}+}+\mathrm{ne}^{-}
\end{aligned}
$$

where $\mathrm{n}$ is either 1 or 2 .

The A-term in Equation (4.1) corresponds to a diffusion-type contribution and the B-term to a process involving the linear growth of a resistive layer. (If resistance is linear with time, current is inversely related to time). Expressed in the form of a sum, the coefficients $A$ and $B$ should give an indication of the relative importance of these two dynamic parts of the process.

As shown in Figure 4.12, the coefficients $A$ and $B$ appear to be inversely related to each other. As $A$ increases in magnitude, $B$ becomes smaller. In other words, the more important diffusion is in limiting the current density, the less important the linear growth term is, and visa versa. Figure 4.13 shows that, for all of the alumina concentrations examined, A is largest at low current densities and decreases almost linearly with increasing current density. B, on the other hand, is smallest at low current densities and increases almost linearly with increasing current density. The relationship of the terms $A$ and $B$ also appears to show a dependency on alumina concentration that will be discussed later.

(a) The oxygen-containing ionic species is given as $0^{2-}$ for simpliçity. Actually the species have been identified as $\mathrm{Aly}_{2} \mathrm{OF}_{6}^{2-}$ and $\mathrm{Al}_{2} \mathrm{O}_{4}-$ (Sterten 1980). 


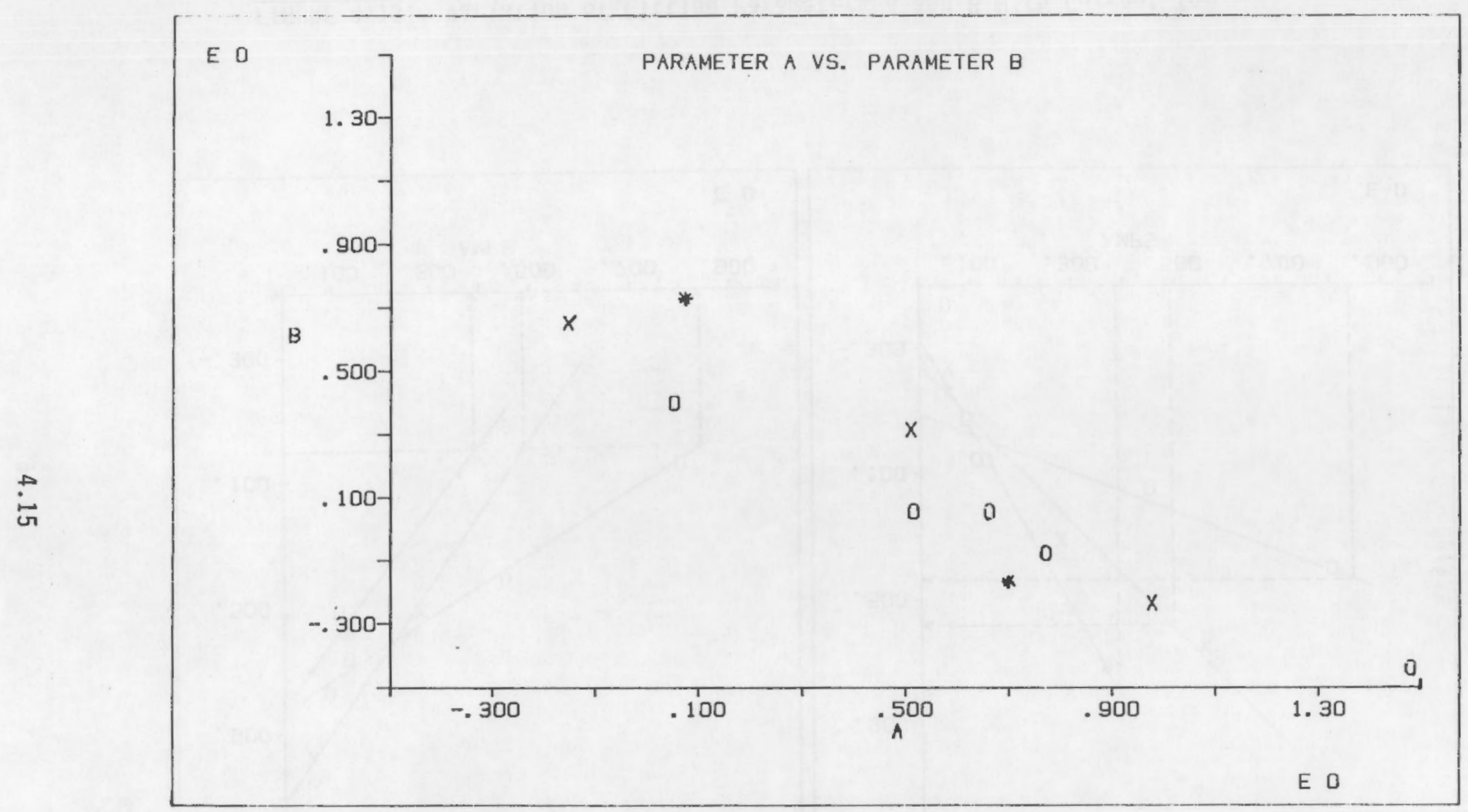

FIGURE 4.12. Plot of Fitting Parameter A Versus Fitting Parameter B for $100 \%(0), 75 \%(x)$ and $50 \%(*)$ Alumina. 

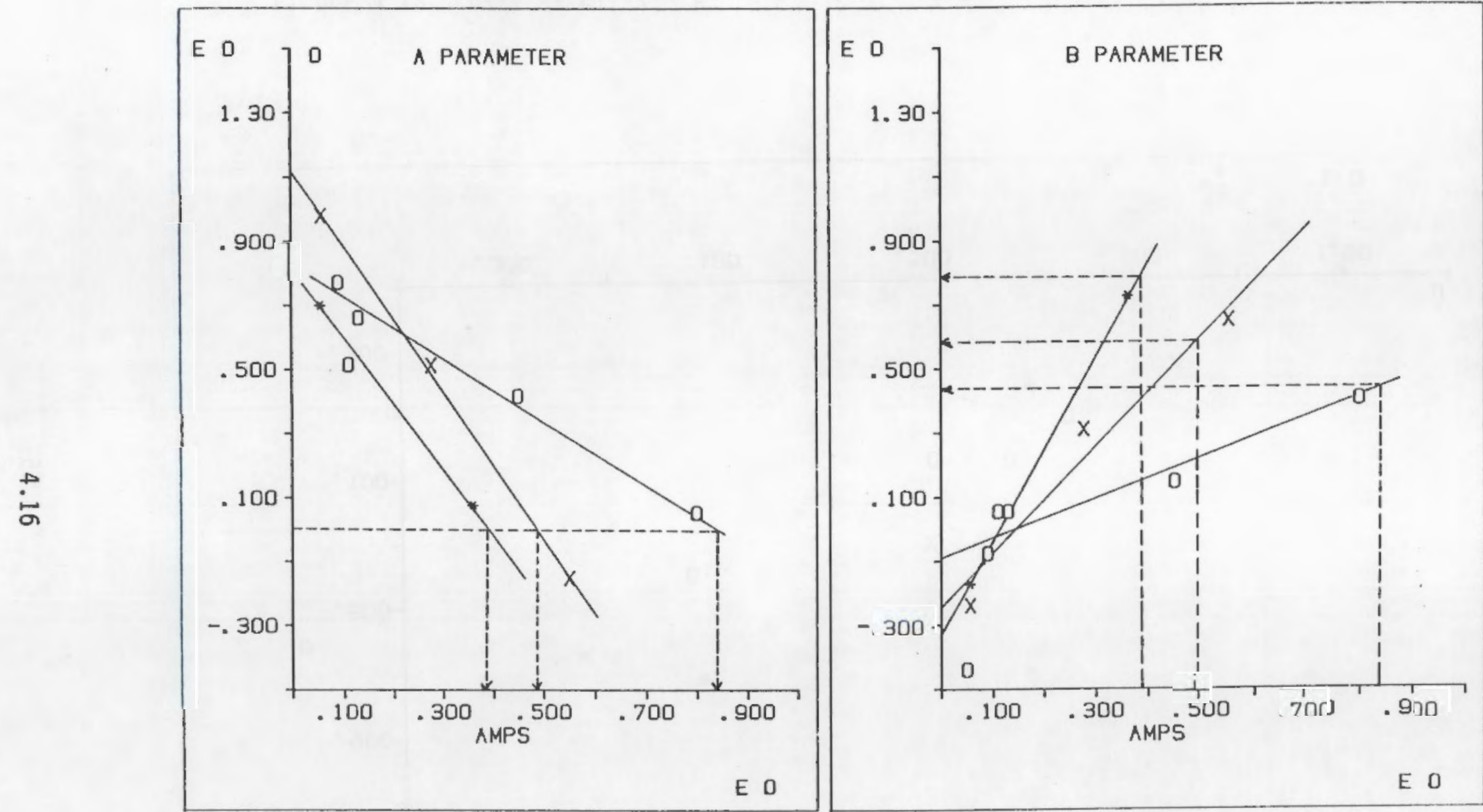

FIGURE 4.13. Variation of Fitting Parameters A and B With Current for $100 \%(0), 75 \%(X)$ and $50 \%\left({ }^{*}\right)$ Alumina. (Dashed lines are for developing Figure 4.19. See text.) 
The above results suggest that a diffusion-limited process is important at low current densities and a process involving the linear growth of a resistive layer is important at high current densities. At intermediate current densities (the exact value depends on alumina concentration), both the diffusion and linear growth terms are current limiting.

Similar conclusions are reached by considering Equation (4.2). Figure 4.14 shows how coefficients $C$ and $D$ vary with current density. $D$ varies from about 0.5 at low current density to about 1.0 at high current density, again suggesting the transition from a diffusion-type process to a linear growthtype process with increasing current density. The values for $C$ do not appear to contain much relevant information.

\subsection{A PHYSICAL MODEL}

A physical model can be derived from the mathematical relationship in Equation (4.1) by first recognizing that the total cell current is the sum of currents from the reactions expressed by Equations (4.3), (4.4) and (4.5). The oxygen production reaction illustrated by Equation (4.3) occurs mostly on the surface of the anode and the corrosion reactions expressed by Equations (4.4) and (5.5) occur mainly in the anode's pores (Tarcy 1986). Thus, the total current can be expressed as the following:

$$
I_{\text {Corr }}+I_{\text {ox }}^{S}
$$

where I Corr is the current from corrosion reactions in the pores and $I_{0 x}^{S}$ is the current from oxygen production occurring mainly on the anode's outer surface.

\subsubsection{Low Current Density Behavior}

The decomposition potential for alumina is $2.2 \mathrm{~V}$ versus the $\mathrm{Al}_{1} / \mathrm{Al}_{2} \mathrm{O}_{3}$ electrode. Consequently, current produced below (or near) this potential predominantly arises from the corrosion reactions illustrated by Equations (4.4) and (4.5), (a) and occurring primarily in the pores of the anode.

(a) Some sub-decomposition potential production of oxygen may also contribute to this current although its role is probably minor (Tarcy 1986).

\subsection{7}




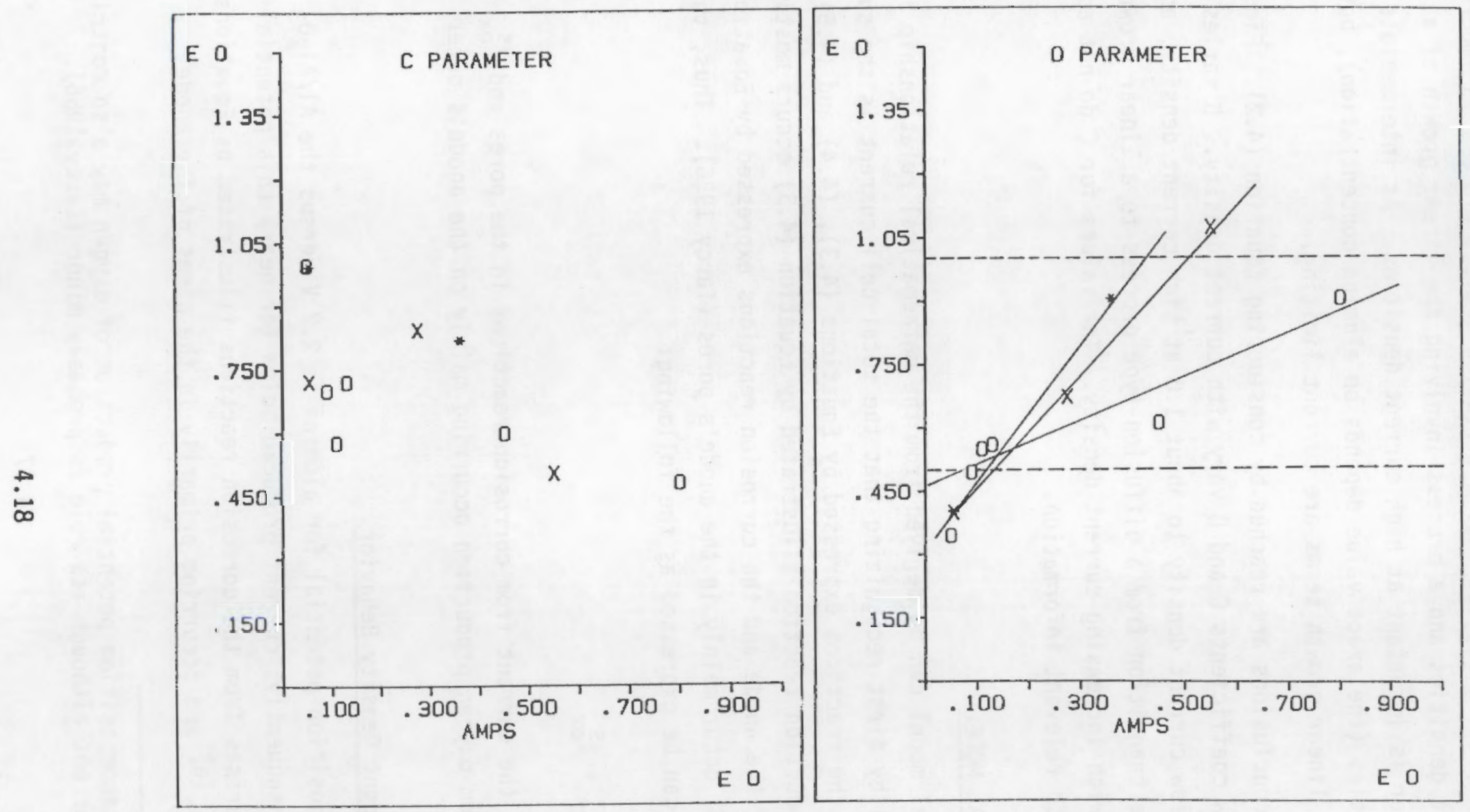

FIGURE 4.14. Variation of Fitting Parameters $C$ and $D$ with Current for $100 \%(0), 75 \%(\mathrm{X})$ and $50 \%\left({ }^{*}\right)$ Alumina. 


$$
I=I_{\text {corr }} \quad \text { (low cd) }
$$

This supposition is supported by post-mortem microscopy at PNL of cermet inert anodes polarized at potentials below $2.2 \mathrm{~V}$. Figure $4.15 \mathrm{a}$ is an optical micrograph of an unpolarized anode submerged momentarily in molten cryolite; Figure $4.15 \mathrm{~b}$ shows an anode polarized at $2.1 \mathrm{~V}$ for $1 \mathrm{~h}$ (Figure $4.15 \mathrm{c}$ will be discussed later). The darker regions in the cermet portions of both micrographs are oxide phases; the very light phase is metallic. Only the bottom surface of the anode was exposed to the electrolyte. A comparison of Figures $4.15 \mathrm{a}$ and $4.15 \mathrm{~b}$ shows that the surface region of the polarized anode degraded severely. The degradation was characterized by increased porosity and loss of the metallic phase. Clearly, corrosion reactions are important at relatively low anode potentials.

The potential-step data suggest that the low current density data is diffusion limited, which is also consistent with the reactions occurring in pores. Corrosion of the metal phase in similar cermet anodes was previously proposed (Tarcy 1986) to be diffusion limited and occur in pores. In addition, diffusion-controlled anodic reactions occurring on some types of carbon anodes have been explained by considering the porosity of the carbon (Thonstad 1970). As shown in Figure 4.16, EIS data for the cermet inert anode at $2.1 \mathrm{~V}$ in alumina-saturated molten cryolite are also consistent with a diffusion-limited reaction and with the role of porosity. The Nyquist plot (or a plot of the real part, $Z^{\prime}$, versus the imaginary part, $-Z^{\prime \prime}$, of the complex impedance) shows a low-frequency region that is characterized by an apparently linear increase of $-Z^{\prime \prime}$ with $Z^{\prime}$. This is typical for a Warburgtype diffusion (Bard and Faulkner 1980). For planar electrodes the phase angle, or inverse tangent of the slope of this line, should be 45 degrees. For porous electrodes (delevie 1967), the phase angle will be less than 45 degrees (ideally, 22.5 degrees for semi-infinite pores). The measured phase angle is 32 degrees, again consistent with the behavior of a porous electrode. 


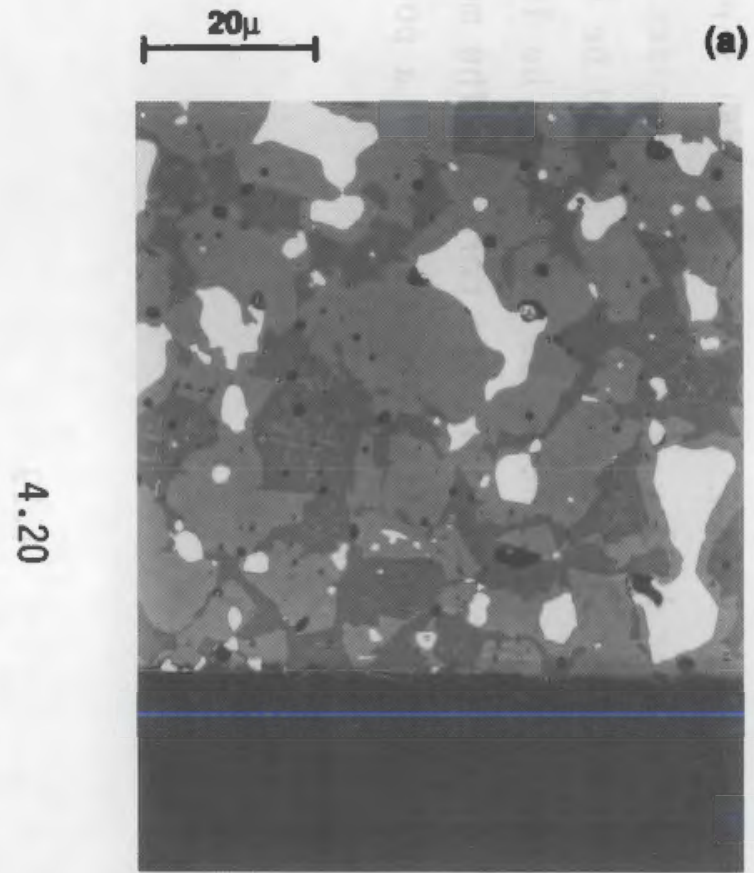

Control

No Electrolysis

(b)

(c)

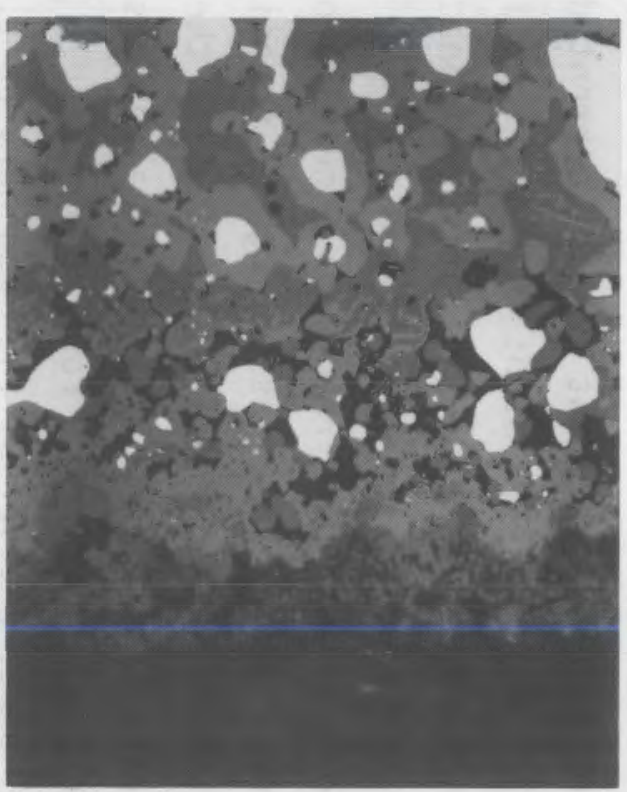

$2.1 \mathrm{~V}$ vs $\mathrm{Al}_{2} / \mathrm{Al}_{2} \mathrm{O}_{3}$

$70 \mathrm{~mA} / \mathrm{cm}^{2}$

B.R. $=1.15 ; 75 \% \mathrm{NLO}_{3}$

$983^{\circ} \mathrm{C}$; 1 hour

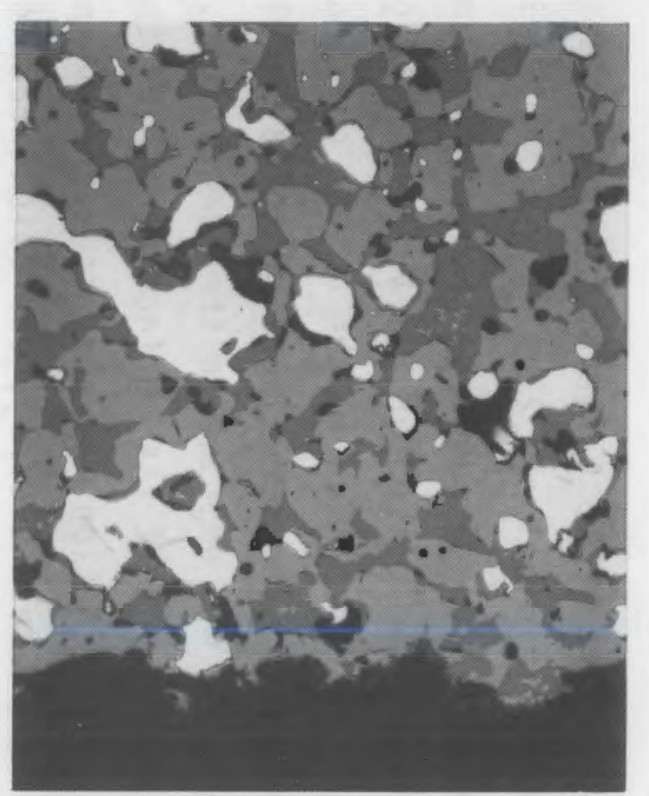

$2.7 \mathrm{~V}$ v8 $\mathrm{Al} / \mathrm{Al}_{2} \mathrm{O}_{3}$

$1 \mathrm{Acm}{ }^{2}$

B.R. $=1.15 ; 75 \% \mathrm{Al}_{2} \mathrm{O}_{3}$ 983 $\mathrm{C}$; 1 hour

FIGURE 4.15. Optical Micrographs for PNL Cermet Inert Anodes. 


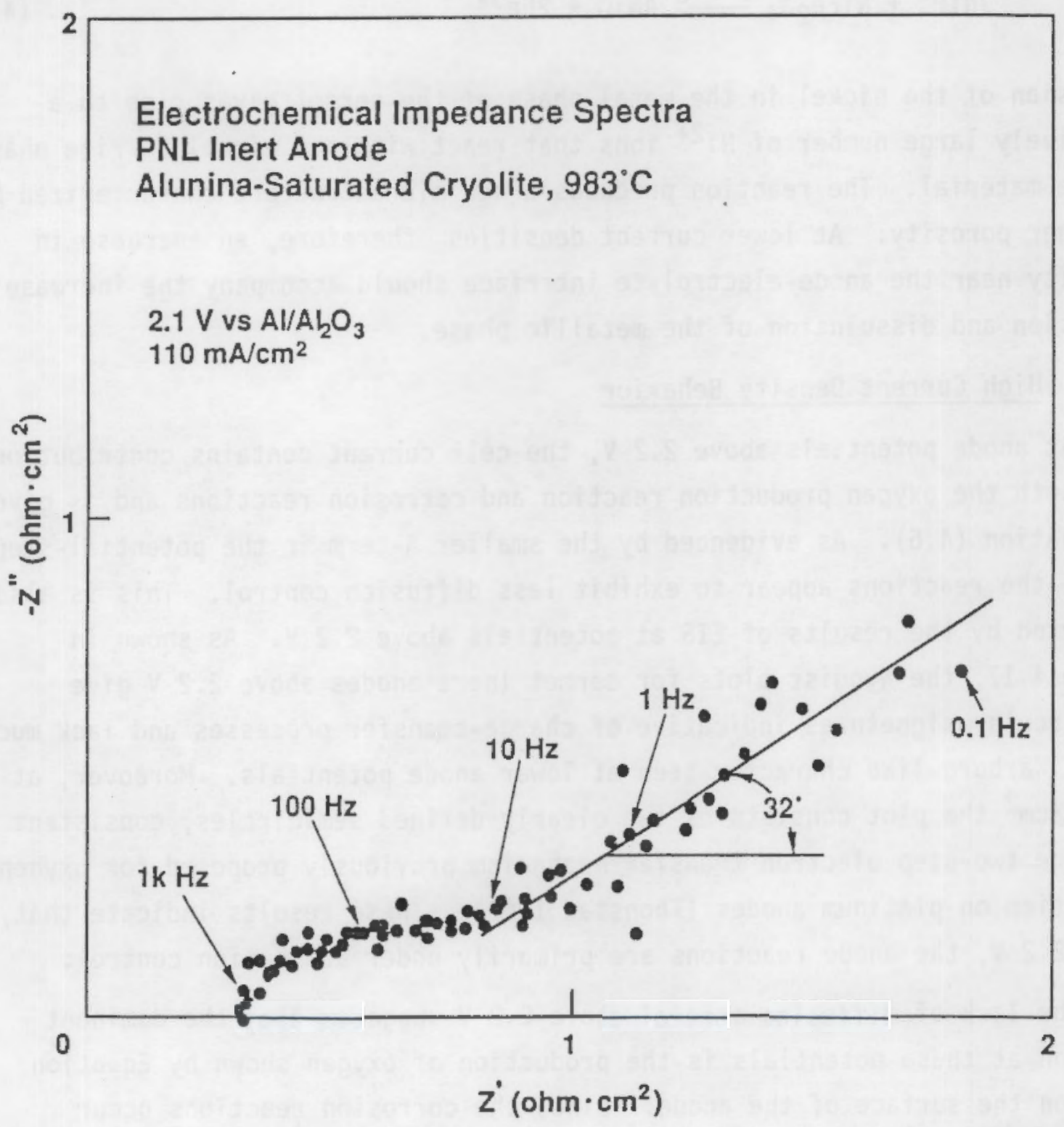

39001061.7

FIGURE 4.16. Electrochemical Impedance Spectra for PNL Inert Anode at 2.1 Volts. 
The increased porosity observed on anodes polarized at lower current densities can be explained by the following parasitic reaction which was proposed to occur in nicke1-containing cermets (Tarcy 1986):

$$
3 \mathrm{Ni}^{2+}+\mathrm{NiFe}_{2} \mathrm{O}_{4} \longrightarrow 4 \mathrm{NiO}+2 \mathrm{Fe}^{3+}
$$

Corrosion of the nickel in the metal phase of the cermet gives rise to a relatively large number of $\mathrm{Ni}^{2+}$ ions that react with the nickel ferrite phase of the material. The reaction produces a new microstructure characterized by a higher porosity. At lower current densities, therefore, an increase in porosity near the anode-electrolyte interface should accompany the increase in corrosion and dissolution of the metallic phase.

\subsubsection{High Current Density Behavior}

At anode potentials above $2.2 \mathrm{~V}$, the cell current contains contributions from both the oxygen production reaction and corrosion reactions and is given by Equation (4.6). As evidenced by the smaller A-term in the potential-step tests, the reactions appear to exhibit less diffusion control. This is also supported by the results of EIS at potentials above $2.2 \mathrm{~V}$. As shown in Figure 4.17, the Nyquist plots for cermet inert anodes above $2.2 \mathrm{~V}$ give semicircular signatures indicative of charge-transfer processes and lack much of the Warburg-like character seen at lower anode potentials. Moreover, at $440 \mathrm{~mA} / \mathrm{cm}^{2}$ the plot consists of two clearly defined semicircles, consistent with the two-step electron transfer mechanism previously proposed for oxygen production on platinum anodes (Thonstad 1968). These results indicate that, above $2.2 \mathrm{~V}$, the anode reactions are primarily under activation control.

The lack of diffusion control above $2.2 \mathrm{~V}$ suggests that the dominant reaction at these potentials is the production of oxygen shown by Equation (4.3) on the surface of the anode. Since the corrosion reactions occur primarily in pores, the small role of diffusion is indicative that these reactions provide little contribution to the steady-state current at potentials above $2.2 \mathrm{~V}$.

$$
I=I_{o x}^{S} \quad \text { (high cd, steady-state) }
$$




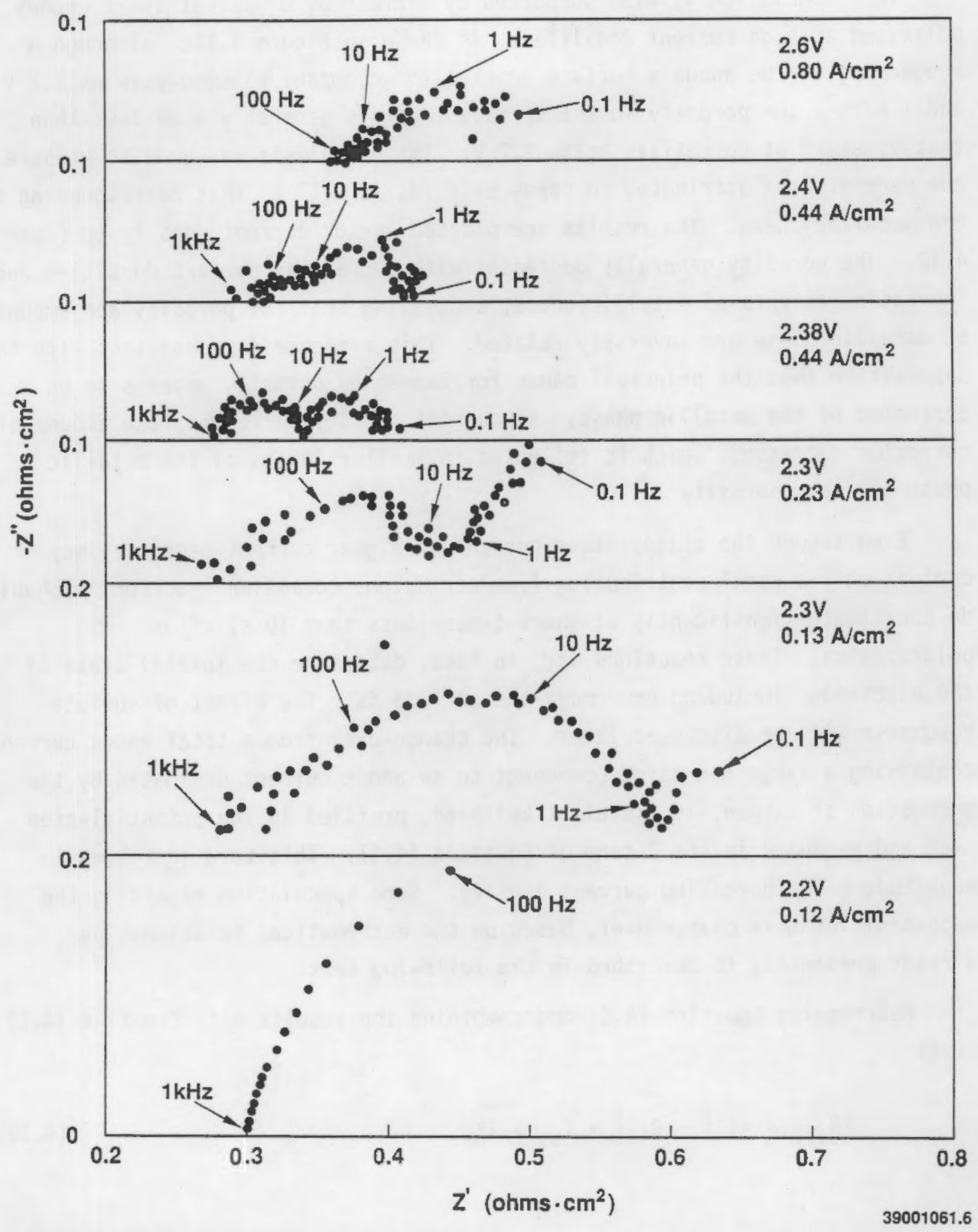

FIGURE 4.17. Electrochemical Impedance Spectra for PNL Inert Anodes at Potential Above 2.1 Volts. 
This conclusion is also supported by microscopy of cermet inert anodes polarized at high current densities. As shown in Figure $4.15 \mathrm{c}$, although a roughening of the anode's surface appears to accompany electrolysis at $2.7 \mathrm{~V}$ and $1 \mathrm{~A} / \mathrm{cm}^{2}$, the porosity in the surface layer is generally much less than that observed at potentials below $2.2 \mathrm{~V}$. Image analysis was used to measure the percent area attributed to pores or voids as well as that corresponding to the metallic phase. The results are plotted versus current density in Figure 4.18. The porosity generally decreases with increasing current densities and increasing amounts of metallic phase, suggesting that the porosity and amount of metallic phase are inversely related. This evidence is consistent with the supposition that the principal cause for increased porosity appears to be corrosion of the metallic phase. As current density increases, the amount of corrosion decreases, which is reflected in smaller losses of the metallic phase and less porosity.

Even though the steady-state current at higher current densities may contain only a small contribution from corrosion, corrosion reactions probably do contribute significantly at short times (less than $10 \mathrm{~s}$ ) after polarization. These reactions may, in fact, determine the initial state of the electrode, including how rough the surface is. The effect of surface roughness will be discussed later. The change-over from a total anode current containing a large corrosion component to an anode current dominated by the production of oxygen, is, in all likelihood, profiled in the potential-step data and embodied in the B-term of Equation (4.1). This term increases in magnitude with increasing current density. Some speculation regarding the mechanism for this change-over, based on the mathematical relationships already presented, is described in the following text.

Rearranging Equation (4.6) and combining the results with Equation (4.1) gives

$$
I R_{\text {corr }}=A t^{-\frac{1}{2}}+B t^{-1}+I_{S S}-I_{O x}^{S}
$$



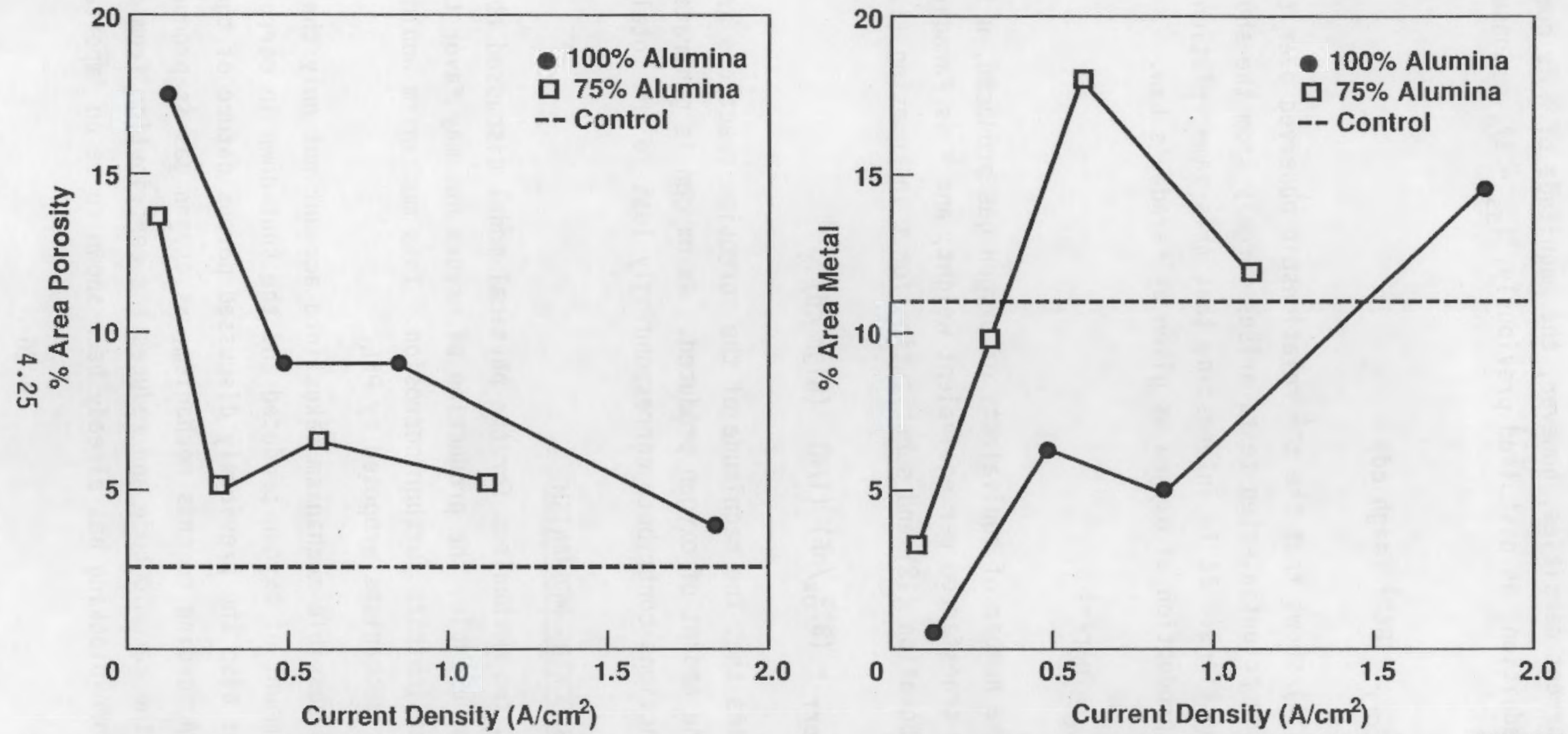

39001061.2

FIGURE 4.18. Porosity and Metal Phase Relationships in $0.50 \mu$ Surface Region on PNL Cermet Inert Anodes. Data are for $100 \%(\bullet)$ and $75 \%$ (ם) Alumina and for an Unpolarized Specimen (---). 
At higher current densities, however, the magnitude of $A$ is comparatively smal1. In addition, as discussed previously, $I_{S S}=I_{\text {ox }}^{S}$. Consequently, we can write

$$
I_{\text {Corr }}=B t^{-1} \text { (high } c d \text { ) }
$$

Equation (4.11) shows that the $t^{-1}$ relationship observed over the first 10 seconds in the potential-step tests arises largely from the shut-down of the corrosion reactions. It is interesting that this same relationship describes the rate of production of oxygen as given by Faraday's Law.

$$
I_{0 x}^{5}=\mathrm{NnFt}^{-1}
$$

where $N$ is the number of equivalents of oxygen gas produced, $n$ is the number of electrons transferred per equivalent weight, and $F$ is Faraday's constant. Rearranging Equation (12) and substituting for $t$ in Equation (11) gives

$$
I_{\text {orr }}=\left(\mathrm{BI}_{\mathrm{Ox}}^{\mathrm{S}} / \mathrm{nF}\right)(\mathrm{T} / \mathrm{N}) \quad(\text { high } \mathrm{Cd})
$$

which indicates that the magnitude of the corrosion reactions are inversely related to the amount of oxygen produced. As oxygen is generated, the corrosion reactions contribute correspondingly less to the total current.

\subsection{A PORE-BLOCKING MECHANISM}

At least two mechanisms for the physical mode1 discussed above are possible. For example, the production of oxygen gas may favor the formation of a film that inhibits further corrosion. This mechanism would be consistent with previous mechanisms proposed by PNL.

A second possible mechanism takes into account not only the relationship between the amount of oxygen produced and the shut-down in corrosion reactions, but also the previously discussed porous nature of the cermet electrodes. According to this mechanism, as oxygen gas is produced it plugs the pores in the ceramic body and reduces the contribution from corrosion reactions. Pore-blocking has already been shown to be an important part of 
the corrosion behavior of cermets containing nickel metal (Tarcy 1986). Therefore, it should not be surprising that the phenomenon also contributes to the behavior of copper-containing cermets.

This second mechanism has a number of distinct advantages over the filmforming mechanism. Minimal diffusion effects should be observed at these current densities if most of the oxygen gas is produced on the surface of the electrode. This prediction is consistent with the potential-step and EIS data. If a film were formed as previously proposed, transport across it would give rise to some diffusional characteristics, particularly if the film is resistive as previous reported. Lack of diffusion control leaves the question of charge transport across the film unanswered. In addition, the existence of the pore-blocking mechanism eliminates the need to "find" and unequivocally identify a reaction layer or film.

\subsection{THE RELATIONSHIP BETWEEN FITTING PARAMETER B AND THE CONCENTRATION OF ALUMINA}

The pore-blocking theory is also consistent with the way in which the corrosion processes are influenced by alumina concentration.

The mechanism (Thonstad 1968) for the production of oxygen gas on an inert electrode (Pt) is the following:

$$
\begin{aligned}
& \mathrm{O}^{2-} \stackrel{\mathrm{k}_{1}}{\longrightarrow} \mathrm{O}(\mathrm{ad})+2 \mathrm{e}^{-} \\
& \mathrm{O}^{2-}+\mathrm{O}(\mathrm{ad}) \stackrel{\mathrm{k}_{2}}{\longrightarrow} \mathrm{O}_{2}(\mathrm{ad})+2 \mathrm{e}^{-} \\
& \mathrm{O}_{2}(\mathrm{ad}) \stackrel{\mathrm{k}_{3}}{\longrightarrow} \mathrm{O}_{2}(\mathrm{~g})
\end{aligned}
$$


where the $k$ values are the various rate constants and (ad) refers to adsorbed species. Based on this mechanism, the overall reaction rate of oxygen production at the anode surface, $\mathrm{dX}^{5} / \mathrm{dt}$, is (a)

$$
d X^{5} / d t=k_{1} C^{1}
$$

where $C^{\prime}$ is the concentration of oxide ion $0^{2-}$ in moles per $\mathrm{cm}^{3}$ of molten electrolyte.

Using the chain rule,

$$
\left(d R P_{x} / d t\right)\left(d X P / d R P_{x}\right)\left(d X^{S} / d X^{P}\right)=k_{1} C^{\prime}
$$

where $\left(d R R_{x} / d t\right)$ is the rate of increase in electrical resistance resulting from oxygen infusing the pores, $\left(\mathrm{dXP} / \mathrm{dR}_{\mathrm{gx}}\right)$ is the reciprocal of resistance per amount of oxygen gas in the pores $(r)$, and $\left(d X^{S} / d x^{p}\right)$ is the reciprocal of the fraction of the oxygen produced on the surface that finds its way into the pores ( $f$ ). Rewriting the above equation,

$$
\mathrm{dR}_{\mathrm{dx}} / \mathrm{dt}=\mathrm{frk}_{1} \mathrm{C}^{\prime}
$$

Rearranging and integrating Equation (4.19) gives

$$
R_{b x}=f r k_{1} C^{\prime} t
$$

The constant of integration is zero since the initial amount of oxygen in the pores is taken as zero along with the initial $R_{b x}$.

Using Ohm's Law, the corrosion current in the pores is therefore given by

$$
I_{\text {corr }}=V P / R P_{D x}=\left(V P / f r k_{1} C^{\prime}\right)(1 / t)
$$

where VP is the "pore potential."

(a) Derived by using the steady-state approximation on the adsorbed species $O(\mathrm{ad})$ and $\mathrm{O}_{2}(\mathrm{ad})$. 
Comparison of Equation (4.11) and Equation (4.21) gives

$$
B=\left(V P / f r k_{1}\right)\left(1 / C^{\prime}\right)
$$

or

$$
B=\left(V P / 3 f r k_{1}\right)(1 / C)
$$

where $C$ is the concentration of alumina in moles per $\mathrm{cm}^{3}$ of molten electrolyte.

Assuming ( $\left.\mathrm{VP} / 3 \mathrm{frk}_{1}\right)$ is constant, as a first approximation, (a) and that the mechanism holds throughout the range of alumina concentrations, Equation (4.23) says that a plot of fitting parameter $B$ for various concentrations of alumina versus $1 / C$ is a straight line with a $B$-intercept equal to zero.

Fitting Parameter B was determined from Figure 4.12 for alumina concentrations equal to $100 \%, 75 \%$, and $50 \%$ of saturation. The appropriate value for $B$ was selected by first determining the current density when $A$ was equal to zero. At this current density the contribution from the A-term was considered acceptably small (consistent with the use of Equation (4.11) in the above derivation). The value of $B$ for this current density was subsequently determined. A plot of $B$ determined in this way versus $1 / C$ is given in Figure 4.19; the data used for this plot given in Table 4.2. As expected from the previous discussion, the plot is linear with a B-intercept very close to zero. This result not only supports the mechanism for oxygen production discussed above, but shows that the B-term and its connection with the corrosion processes are tied to oxygen production during the early stages of polarization. The calculations also show that a pore-blocking mechanism may explain the interrelationship.

(a) Actually, some of the parameters in this term should vary with current density, particularly VP and $k_{1}$. They may vary, however, in such a way as to be self-negating. For example, VP and $k_{1}$ should both increase with current density, so their quotient may not change appreciably. Nevertheless, further work is warranted to resolve this uncertainty. 


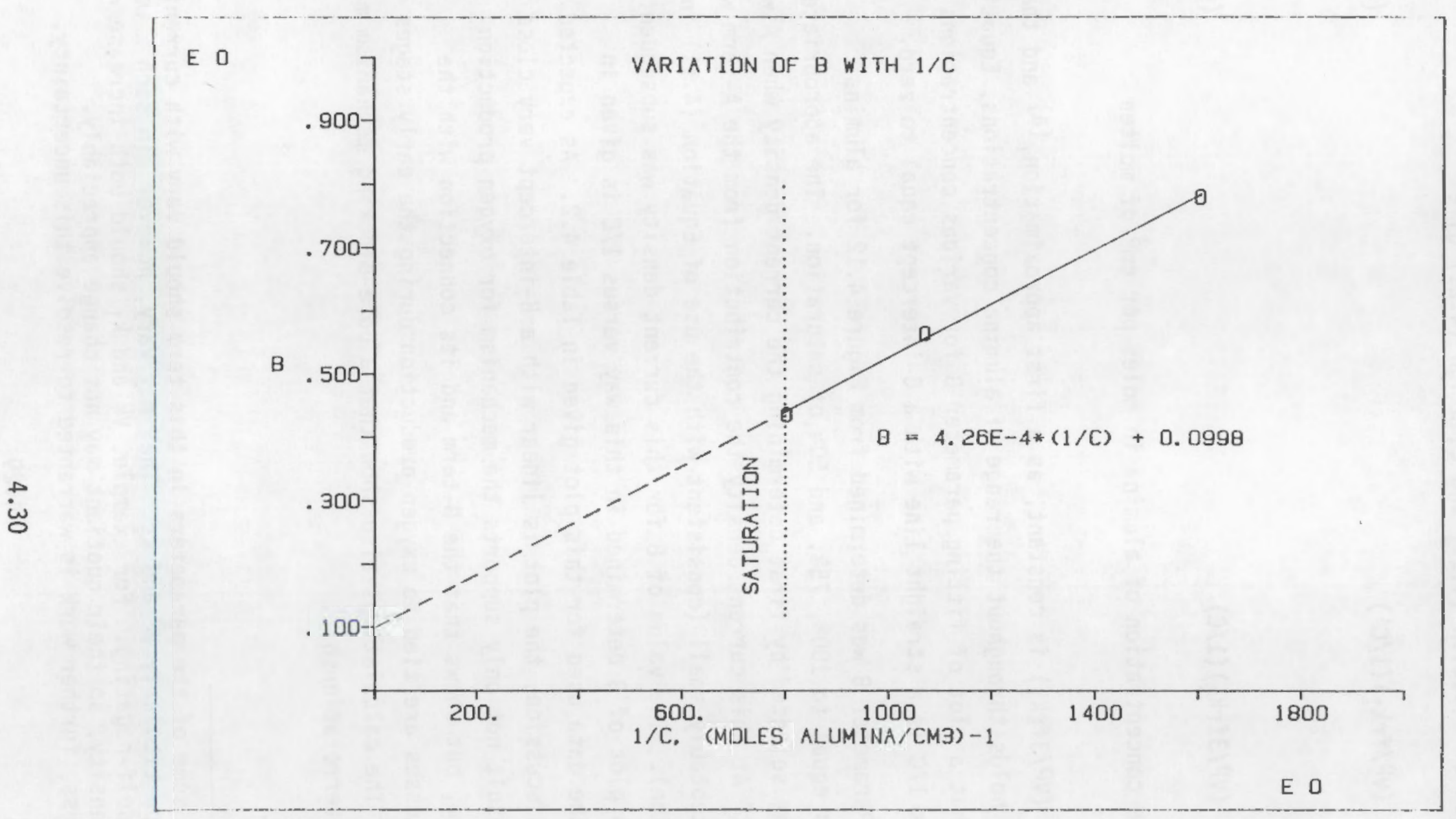

FIGURE 4.19. Variation of Fitting Parameter B with $1 / C$ where $C$ is the Alumina Concentration in Moles $/ \mathrm{cm}^{3}$. 


\section{TABLE 4.2. Data For Plotting Parametęr B Against Aluminum Concentration in Moles $/ \mathrm{cm}^{3}$}

\begin{tabular}{|c|c|c|c|c|}
\hline $\begin{array}{c}\mathrm{Al}_{2} \mathrm{O}_{3}(\%) \\
\text { of Saturation } \\
\end{array}$ & $\mathrm{Al}_{2} \underline{\mathrm{O}}_{3}(\mathrm{wt} \%)$ & $c\left(\mathrm{~mole} / \mathrm{cm}^{3}\right)$ & $1 / \mathrm{C}$ & $B($ When $A=0)$ \\
\hline $\begin{array}{l}100 \\
75 \\
50\end{array}$ & $\begin{array}{l}6.0 \\
4.5 \\
3.0\end{array}$ & $\begin{array}{l}1.25 \mathrm{E}-3 \\
9.35 \mathrm{E}-4 \\
6.24 \mathrm{E}-4\end{array}$ & $\begin{array}{r}802 \\
1070 \\
1603\end{array}$ & $\begin{array}{l}0.436 \\
0.564 \\
0.780\end{array}$ \\
\hline
\end{tabular}

\subsection{AN EXPLANATION FOR THE ANODE IMPEDANCE RELATIONSHIP}

If a pore-blocking process is responsible for the reduction in the extent of corrosion of the metallic phase of the cermet anodes at higher current densities, then an explanation for the impedance previously associated with a protective film is required. (a) Examination of Figure $4.15 \mathrm{c}$ reveals that a certain surface roughening appears to accompany polarization of the anode at higher current densities. The roughness was measured ${ }^{(b)}$ for anodes polarized for identical times using the same conditions except for potential, current density, and alumina concentration. As shown in Figure 4.20, the surface roughness, quantified by parameters $x$ and $s$, generally decreased as current density increased to about $0.5 \mathrm{~A} / \mathrm{cm}^{2}$. Above $0.5 \mathrm{~cm}^{2}$, the roughness factors again increased dramatically.

Examination of Figure $4.15 \mathrm{~b}$ shows that surface roughening accompanies the corrosion reactions at lower current densities. Figure $4.15 \mathrm{c}$ shows that the roughening also occurs at higher current densities, although from a presently unexplained source. As mentioned previously, corrosion reactions occurring very shortly after polarization may determine a characteristic morphology on

(a) The possibility that a film contributes to the impedance has not been eliminated. Optical microscopy has revealed the presence of a reaction layer, and its analysis is in progress. However, preliminary inspection shows that its characteristics such as thickness, unlike the surface roughness, do not seem to correlate with the measured impedance.

(b) Surface roughness was determined by computing the mean, $x$, and standard deviation, $s$, of numerous measurements of the distance between the anode's surface and a reference point using optical micrographs of the anode sample. $x$ gives an indication of the "depth" of the roughness, and $s$ measures the extent of "bumpiness." 
the anode's surface. Despite this uncertainty, however, the roughness may help explain the impedance relationships observed in previous PNL studies.

The variation in surface roughness with current density, similar to the relationship involving cell impedance, $\left({ }^{a}\right)$ is shown in Figure 4.20. Impedance is highly dependent on cell geometry, including electrode area and topography. It is possible, therefore, that the observed relationship between impedance and current density is caused by changes in surface roughness which, in turn, are determined by the anodic current density.

One possible explanation for the observed correlations is that only a portion of the total surface area is active, i.e. serves as a substrate on which the oxide ions are discharged. On a rough surface, the active regions would probably be those areas which protrude the most into the electrolyte. Recessed areas may be blocked by gas bubbles or, perhaps, solid, poorly conducting corrosion products. In any event, as a result of the roughening, a large portion of the surface area is rendered inactive, causing the "real" surface area to be less than that which is "apparent." The resulting impedance would be larger than expected.

The above explanation for the variation in cell impedance can also help explain certain issues that were puzzling in the context of the alternative film-formation theory. First, the increase in impedance at lower current densities could not be explained because a protective film was not formed appreciably under these conditions. Also, in a number of previous studies at PNL it was observed that the anode impedance could be preserved when the anode was removed from the molten electrolyte and used at a later date in another cell. This observation was explained by proposing that the film which formed on the anode could be preserved during the transfer, i.e. the film formed in the molten electrolyte under polarization conditions could exist intact on the electrode after its removal. This explanation was somewhat suspect since microscopic examination gave no unequivocal evidence for such an intact layer. It was also improbable that the film could retain its chemical integrity

(a) This impedance was determined from the high-frequency $Z^{\prime}$-intercept of the plots in Figures 4.16 and 4.17 . The values, determined in this way, follow the same relationship with current density reported previously (Strachan 1988) and correspond primarily to the electrolyte resistance. 

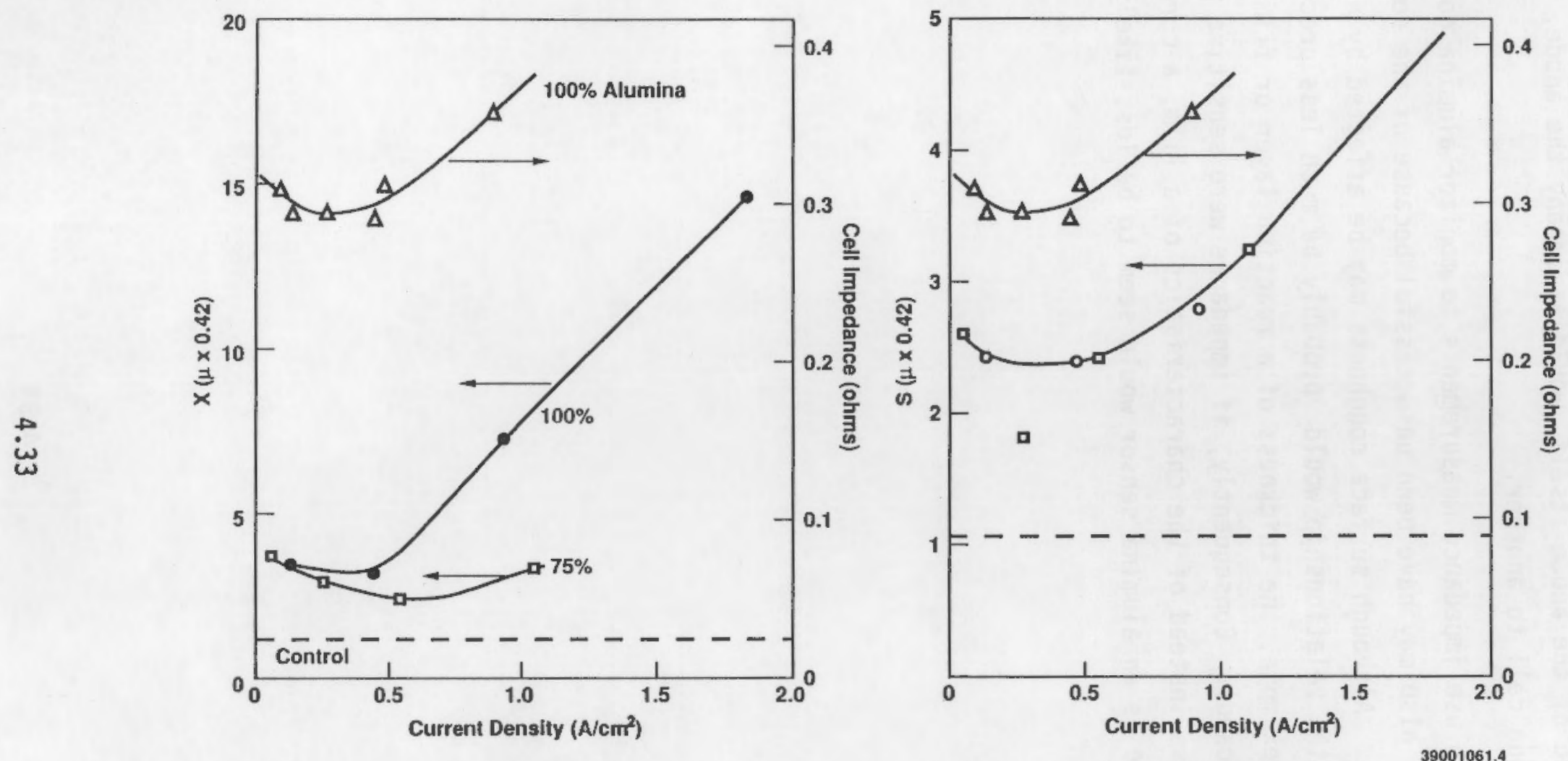

FIGURE 4.20. Relationships of Impedance and Roughness Factors $X$ and $S$ for PNL Cermet Inert Anodes. Data Are For $100 \%(\bullet, \Delta)$ and $75 \%$ (a) Alumina and For an Unpolarized Specimen. 
considering the drastic physical and chemical changes accompanying the electrode transfer. It is more likely that the effects of surface roughness, a characteristic of the anode itself, would accompany the anode, surviving a transfer from one cell to another.

Attempts to use impedance measurements to monitor alumina concentration (Windisch 1990) also may have been unsuccessful because of the source of the anode impedance. Although surface roughness may be affected by alumina concentration, the relationship would probably be much less precise than one involving, for example, the thickness of a reaction layer or film (as previously proposed). Consequently, if impedance were sensitive primarily to surface roughness instead of the characteristics of a $f i l m$, a correlation adequate for use as an alumina sensor would seem to be less likely. 


\subsection{CONCLUSIONS}

The results of potential-step studies, electrochemical impedance spectroscopy, and post-mortem microscopic analysis of polarized anodes suggest that the processes of corrosion of the metallic phase of the cermet anode and the production of oxygen gas are separable and exhibit very different kinetic behavior. The corrosion reactions occur predominantly at low anode potentials, appear to show diffusion control, and may be related to the porosity of the anode. The oxygen production reaction is the predominant reaction above $2.2 \mathrm{~V}$, shows activation control, occurs primarily on the surface of the anode, and is accompanied by an increase in surface roughness at higher current densities. These studies suggest that the production of oxygen shuts down the corrosion reactions, possibly through a pore-blocking mechanism, and contributes to a surface roughening that may help explain some of the impedance relationships previously observed by PNL for the cermet inert anodes. The formation of a protective layer or film is not unequivocally ruled out by the results of these studies. However, alternative mechanisms for the apparent attenuation of corrosion reactions at typical operating current densities should be considered more viable explanations of observed behavior. In particular, the effects of surface porosity and roughness should be more closely examined as indicators (or predictors) of long-term corrosion behavior. 
. -

-

.

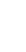




\subsection{REFERENCES}

Bard, A. J., and L. R. Faulkner. 1980. Electrochemical Methods. John Wiley and Sons, Inc., New York.

Burgman, J. W., J. A. Leistra, and P. J. Sides. 1986. "Aluminum/Cryolite Reference Electrodes for Use in Cryolite-Based Melts." J. Electrochem. Soc. $133(3): 496-500$.

deLevie, R. 1967. Advances in Electrochemistry and Electrochemical Engineering: Volume 6. Interscience, Wiley, New York.

Macdonald, D. D. Transient Techniques in Electrochemistry. 1977. Plenum Press, New York.

Sato, N., and M. Cohen. 1964. "The Kinetics of Anodic Oxidation of Iron in Neutral Solution." J. Electrochem. Soc. 111(5):512-519.

Sterten, A. 1980. "Structural Entities in $\mathrm{NaF}_{-} \mathrm{AlF}_{3}$ Melts Containing Alumina." Electrochimica Acta. 25:1673-1677.

Strachan, C. M., O. H. Koski, S. C. Marschman, C. H. Schilling and C. F. Windisch. 1988. Fiscal Year 1986 Annual Report for the Inert Electrodes Program. PNL-6746, Pacific Northwest Laboratory, Richland, WA.

Tarcy, G. P. 1986. "Corrosion and Passivation of Cermet Inert Anodes in Cryolite-Type Electrolytes." Light Metals 1986. Warrendale, PA.

Thonstad, J. 1968. "Anodic Overvoltage on Platinum in Cryolite-Alumina Melts." Electrochimica Acta. 13:449-456.

Thonstad, J. 1970. "The Electrode Reaction on the $\mathrm{C}, \mathrm{CO}_{2}$ Electrode in Cryolite-Alumina Melts - II. Impedance Measurements." Electrochimica Acta. $15: 1581-1595$.

Windisch, Jr., C. F., and N. D. Stice. 1990. Fiscal Year 1989 Annual Report for the Sensors Development Program. PNL-7309. Pacific Northwest Laboratory, Richland, WA. 
.

.

$+$

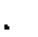




\section{DISTRIBUTION}

No. of

Copies

OFFSITE

M. J. McMonigle

U.S. Department of Energy

Office of Industrial Programs

Forrestal Building

Washington, DC 20585

P. H. Salmon-Cox

U.S. Department of Energy

Office of Industrial Programs

Forrestal Building

Washington, DC 20585

12 DOE Office of Scientific and

Technical Information

C. Anderson

Columbia Aluminum Co.

85 John Day Dan Road

Goldendale, WA 98620

J. V. Anderson

HCVE3

EG\&G Idaho, Inc.

Idaho Falls, ID 83415

D. Auburg

Bonneville Power Administration

P.0. Box 3621, PDX 97208

Portland, OR 97208

F. W. Baker

Ceramics Division

Alcoa Laboratories

Alcoa Center, PA 15069

M. Baltzell

EastaTco Aluminum Company

ATumax, Inc.

5601 Manor Woods

Frederjck, MD 21701
No. of

Copies

J. A. Barclay

U.S. Bureau of Mines

2401 "E" Street N.W.

washington, DC 20241

H. Robert Baumgartner

Ceramics Division

Alcoa Laboratories

Alcoa Center, PA 15069

T. R. Beck

Electrochemical Technology

Corp.

1601 Dexter Avenue

Seattle, WA 98109

S. Berwagan

Bonneville Power Administration

P.0. Box $3621 \mathrm{~K}$

Portland, OR 97208

T. M. Besmann

Metals and Ceramics Division

Oak Ridge National Laboratory

P.0. Box X, Bldg. 4515

Dak Ridge, TN 37831-6063

K. A. Blakely

President

Advanced Refractory

Technologies, Inc.

699 Hertel Ave.

Buffalo, NY 14207

M. H. Blenk

Du Pont

P.0. Box 787

Niagara Falls, NY 14302 
No. of

Copies

L. G. Boxal1

Mart in Marietta Laboratories

1450 South Rolling

Baltimore, MD 21227

J. Bracher

Kaiser Aluminum and Chemical Corp.

825 N.E. Multnomah St., Suite 960

Portland, OR 97232-2150

R. Brandt

Department of Materials Science and Engineering

University of Washington FB-10

Seattle, WA 98195

J. J. Brown, Jr.

Materials Engineering

Virginia Polytechnic Institute

Blacksburg, VA 24061

A. Budner

Bonneville Power Administration

P.0. Box 3621--EPA

Portland, OR 97208

A. J. Caputo

Metals and Ceramics Division

Oak Ridge National Laboratory

P.0. Box $X$

Oak Ridge, TN 37831-6063

N. Clark

Bonneville Power Administration-

Industrial Conservation

P.0. Box 3621

Portland, OR 97208

A. Cooke

Martin Marietta Laboratories

1450 South Rolling

Baltimore, MD 21227
No. of

Copies

J. A. Coppola

Standard 0il Engineered

Materials Company

P.0. Box 156

Niagara Falls, NY 14302

D. D. Cudaback

Director

Washington State Dept of Trade

and Economic Development

312 First Avenue North

SeattTe, WA 98109

R. Curtis

Materials Development

Corporation

81 Hicks Avenue

Medford, MA 02155

J. V. Day

Kaiser Aluminum and Chemical

Corp

E21I1 Hawthorne Road

Mead, WA 99021

R. Dethlefsen

Maxwell Laboratories

8888 Balboa Ave

San Diego, CA 92123

D. H. DeYoung

Alcoa Technical Center

Alcoa Center, PA 15069

S. Diamond

Battelle Columbus Laboratories

505 King Avenue

Columbus, $\mathrm{OH}$ 43201-2693

C. W. Doerr

The Stackpole Corporation

Cermag Division

201 Stackpole Street

St. Marys, PA 15847 
No. of

Copies

T. Dwonch

Snake River District

BPA

101 H. Poplar

Walla Walla, WA 99362

G. L. Eitel

Stone \& Webster Engineering Corp.

Greenwood Plaza Box 5406

Denver, CO 80217

R. Engdahl

Deposits and Composites, Inc.

318 Victory Drive

Herndon, VA 22070

J. F. Elljott

MIT

Room 4-138

77 Massachusetts Avenue

Cambridge, MA 02139

B. G. Epstein

A. D. Little, Inc.

955 Lenfant Plaza SH 4200

Washington, DC 20024-2119

J. W. Evans

University of California

Dept of Mat1. Sci. and Mineral

Eng.

Berkeley, CA 94720

R. A. Fenimore

ICI Advanced Materials

Rollins Building, Eighth Floor

wilmington, DE 19897

D. A. Figgins

ARCO Petroleum Products Co.

P.0. Box 61004

Anaheim, CA 92803-6104
No. of

Copies

P. Foster

Alcoa Laboratories

P.0. Box 772

New Kinsington, PA 15068

J. Gee

Great Lakes Research Corp

P.0. Box 1031

Elizabethton, TN 37643

T. Gilligan

Eltech Systems Corp. 625 East Street

Fairport Harbor, $\mathrm{OH} 44077$

W. M. Goldberger

Superior Graphite Co.

$120 \mathrm{~S}$. Riverside Plaza

Chicago, IL 60606

J. Goodwell

Center for Metals Production

Mellon Institute

$4400 \mathrm{Fifth}$ Avenue

Pittsburgh, PA 15213

J.A.S. Green

Mart in Marietta Laboratories

1450 South Rolling

Baltimore, MD 21227

C. Griffin

Ceramatec Inc.

2425 5. 900 West

Salt Lake City, UT 84119

L. I. Grindstaff

Great Lakes Research Corp.

P.0. Box 1031

Elizabethon, TN 37643

J. Haggerty

MIT

Building 12, Room 009

77 Massachusetts Avenue

Cambridge, MA 02139 
No. of

Copies

I. L. Harry

Electric Power Research Institute

P.0. Box 10412

Palo Alto, CA 94303

W. E. Haupin

2820 7th Street Road

Lower Burre11, PA 15068

\section{R. Hill}

Union Carbide Corp.

P.0. Box 94637

Cleveland, $\mathrm{OH} \quad 44101$

H. F. Hillegass

Alcoa Wenatchee Works

P.0. Box 221

Wenatchee, WA 98807

D. G. Howitt

College of Engineering

University of California, Davis

Davis, CA 95616

F. R. Huettig

Advanced Magnetics, Inc.

45 Corey Lane

Mendham, NJ 07945

G. R. Hyde

U.S. Bureau of Mines

2401 "E" Street N.W.

Washington, DC 20241

S. C. Jacobs

Primary Processing

Aluminum Company of America

Alcoa Technical Center

Alcoa Center, PA 15069

S. H. Jan

Tennessee Valley Authority

1850 Commerce Union Bank Bldg.

Chattanooga, TN 37401
No. of

Copies

N. Jarrett

149 Jefferson Avenue

New Kinsington, PA 15068

J. Johnson

Intalco Aluminum Company

P.0. Box 937

Ferndale, WA 98248

M. H. Johnson

Alcoa Wenatchee Works

P.0. Box 221

Wenatchee, WA 98801

L. Joo

Great Lakes Research Corp

P.0. Box 1031

Elizabethon, TN 37643

M. Karmous

Oregon State Department of Energy

625 Marion Street, N.E.

Salem, OR 97310

R. Keller

RD 3 Roundtop Road

Export, PA 15632

K. Krupinski

Mail Stop 57

U.S. Steel Technical Center

1 Technical Center Drive

Monroeville, PA 15146

G. Y. Lai

Cabot Corporation

P.0. Box 9013

Kokomo, IN 46902-9013

R. A. Landy

Director of Research

North American Refractories Co. 3127 Research Dr.

State College, PA 16801 
No. of

Copies

J. E. Lane

Ceramic Research and

Development Center

Westinghouse Electric

Corporation

1310 Beulah Road

Pittsburgh, PA 15235

Sai-Kwing Lau

Standard $0 i 1$ Engineered

Materials Company

Niagara Falls R\&D Center

P.0. Box 832

Niagara Falls, NY 14302

J. J. Leddy

Dow Chemical U.S.A.

1776 Building

Midland, MI 48640

W. W. Liang

Gas Research Institute

8600 West Bryne Mawr Avenue

Chicago, IL 60631

W. H. Link

Columbia Aluminum Corp.

85 John Day Dam Road

GoldendaTe, WA 98620

Steve Loftness

Washington State Energy Office

$400 \mathrm{E}$. Union

O1ympia, WA 98504

W. Long

Building B815

Dow Chemical

Freeport, Texas 77541

A. G. Longmuir

Kaiser Aluminum and Chemical

Corp.

P.0. Box 877

Pleasonton, CA 94566
No. of

Copies

R. A. Lowden

Metals and Ceramics Division

Oak Ridge National Laboratory

P.0. Box X, Bldg, 4515

Oak Ridge, TN 37831-6063

W. N. Maclay

Koppers Company, Inc.

440 College Park Drive

Monroeville, PA 15146

J. C. McCloskey

Ten Mile River Associates

$296 \mathrm{Mt}$. Hope Street

North Att]eboro, MA 02760

S. C. Manaktala

Manager of Technology

Reduction Division

Kaiser Aluminum and Chemical Corp

300 Lakeside Drive

0akland, CA 94643

V. H. Markant

Du Pont

P.0. Box 787

Niagara Falls, NY 14302

C. J. McMinn

Extractive Metallurgical Department

Reynolds Metals Company

P.0. Box 1200

Sheffield, AL 35660

C. H. McMurtry

Standard 0il Engineered Materials Company

Niagara Falls R\&D Center

P.0. Box 832

Niagara Falls, NY 14302

M. A. Mitnick

Avco Specialty Materials

Subsidiary of Textron Inc.

2 Industrial Avenue

Lowel1, MA 01851 
No. of

Copies

H. Mortensen

R. Palika

Cercom, Inc.

P.0. Box 70

vista, CA 92083

A. Moussa

A. D. Little, Inc.

20 Acorn Park

Cambridge, MA 02140

B. C. Mutsuddy

Battelle Columbus Division

505 King Avenue

Columbus, $\mathrm{OH}$ 43201-2693

P. Ness

Senior Project Manager

Washington State Dept of Trade

and Economic Development

312 First Avenue North

Seattle, WA 98109

A. N. Patel

Battelle Columbus Laboratories

$505 \mathrm{King}$ Avenue

Columbus, $\mathrm{OH}$ 43201-2693

J. R. Payne

Kaiser Aluminum and Chemical Corp.

P.0. Box 877

Pleasanton, CA 94566

T. Payne

Columbia Falls Aluminum Co.

Columbia Falls, MT

W. Pebley

Oregon Freeze Dry Corp.

52525 th Avenue SW

P.0. Box 1048

Albany, OR 97321
No. of

Copies

K. Peterson

Columbia Aluminum Corp.

85 John Day Dam Road

Goldendale, WA 98620

R. D. Peterson

Reynolds Metals Company

P.0. Box 1200

Sheffield, AL 35660

T. R. Pritchett

Kaiser Aluminum and Chemical Corp.

P.0. Box 877

W. W. Pritsky

Aluminum Association

900 19th St. N.W.

Washington, DC 20006

S. P. Ray

Alcoa Technical Center

Alcoa Center, PA 15069

J. F. Rhodes

Advanced Composite Materials Corp.

1525 S. Buncomb Rd.

Greer, SC 29651

N. E. Richards

Reduction Laboratory

Reynolds Aluminum Corporation

P.0. Box 1200

Sheffield, AL 35660

J. J. Ritter

Ceramics Division

National Bureau of Standards

Gaithersburg, MD 20899

R. C. Rohwedder

3028 Ohio Street

Longriew, WA 
No. of

Copies

J. Rosling

Myers Metals and Minerals

459 Colman Building

Seattle, WA 98104

D. R. Sadoway

MIT

Room 8-109

77 Massachusetts Avenue

Cambridge, MA 02139

W. Scott

Department of Materials Science \& Engineering

Wilcox Hall FB-10

University of Washington

Seattle, WA 98195

D. R. Secrist

Great Lakes Research Corp.

P.0. Box 1031

Elizabethon, TN 37643

A. B. Shah

Noranda Aluminum, Inc.

P.0. Box 70

New Madras, M0 63869

N. Shelton

Intalco

1300 S. W. 5th, Suite 3508

Portland, OR 97201

F. W. Spillers

Dow Chemical U.S.A.

B-1210 Building

Freeport, TX 77541

Dr. Richard M. Spriggs

Office of the Director

Center for Advanced

Ceramic Technology

Alfred University

Alfred, NY 14802
No. of

Copies

\author{
D. V. Stewart \\ Reynolds Metals Co. \\ P.0. Box 1200 \\ Sheffield, AL 35660 \\ D. Strahan \\ Reynolds Metals Company \\ P.0. Box 27003 \\ Richmond, VA 23261
}

A. T. Tabereaux

Reynolds Metals Company

P.0. Box 1200

Sheffield, AL 35660

G. P. Tarcy

Aluminum Company of America

Alcoa Technical Center

Alcoa Center, PA 15069

P. Thaure

Primary Planning and Production

Alumax

400 S. El Camino Rd.

San Mateo, CA 94402

W. H. Thielbahr

Conservative Technology

Division

DOE-Idaho Operations Office

785 DOE Place

Idaho FaTls, ID 83402

S. Thomson

General Manager

KTickitat PUD

1313 S. Columbus

Goldendale, WA 98620

R. Unger

Merner Research

P.0. Box 248

Ridgewood, NJ 07451 
No. of

Copies

A. Vinnard
Bonneville Power Administration
(KWI)
P.0. Box 3621
Portland, OR 97208
T. Von Muller-KWI
Bonneville Power Administration
P.0. Box 3621
Portland, 0R 97208
D. H. Weinblatt
AIMCOR
One Parkway North
Deerfield, IL 60015

J. D. Weyand

EG\&G Idaho, Inc.

Idaho Falls, ID 83415

B. Wilcox

Northwest Aluminum Co.

$3313 \mathrm{~W}$. Second St.

The Dalles, OR 97058

C. B. Wilson

Dow Chemical U.S. A.

Texas Operations

B-101 Building

Freeport, TX 77541

J. C. Withers

Keramont Research Corporation

$4233 \mathrm{~S}$. Fremont Avenue

Tucson, AZ 85714

W. A. Zdanjewski

Engelhard Corporation

Menlo Park, CN 28

Edison, NJ 08818

\section{FOREIGN}

D. Brodie

Coma lco Ltd.

55 Collins St.

Melbourne, AUSTRALIA
No. of

Copies
H. Connor

Group Licensing Controller

Johnson Matthey, plc

New Garden House

78 Hatton Garden

London EC1N 8JP ENGLAND

L. Dion

Alcan International Limited C.P. 6090

Montreal, Quebec

CANADA, H3C $3 \mathrm{H} 2$

T. Kjar

Comalco Ltd.

55 Collins st.

Melbourne, AUSTRALIA

E. W. Dewing

Alcan International

P.0. Box 8400

Kingston, Ontario

CANADA K7L $4 Z 4$

D. N. MacMillan

Alcan International

C.P. 1250

Jonquieve, Quebec

CANADA G7S $4 K 8$

J. H. Reimers

Jan H. Reimers and Associates

Inc.

221 Lakeshore Road East

0akville, Ontario

CANADA, L6J $1 \mathrm{H} 7$

A. Oye

Institute of Inorganic Chemistry

Norwegian Institute of Technology

University of Trondheim

N-7034 Trondheim-NTH, NORWAY 
No. of

Copies

3. Thonstad

Laboratories of Industrial

Electrochemistry

Norwegian Institute of

Technology

University of Trondheim

N-7034 Trondheim-NTH, NORWAY

K. 0 . Vee

ASV Ardal Verk

N-5875 Ardalstargen, NORHAY

\section{ONSITE}

DOE - Richland Operations Office
No. of

Copies

25 Pacific Northwest Laboratory

M. Clement

N. C. Davis

D. K. Hitliard

G. L. McVay

N. L. Moore

L. G. Morgan (10)

C. H. Schilling

D. M. Strachan

R. E. Westerman

C. F. Windisch

Publishing Coordination

Technica] Report Files

R. B. Goranson 
. 